Prepared in cooperation with

the Rhode Island Department of Environmental Management, the Rhode Island Water Resources Board, and the U.S. Environmental Protection Agency

\title{
Analysis of Trends of Water Quality and Streamflow in the Blackstone, Branch, Pawtuxet, and Pawcatuck Rivers, Massachusetts and Rhode Island, 1979 to 2015
}

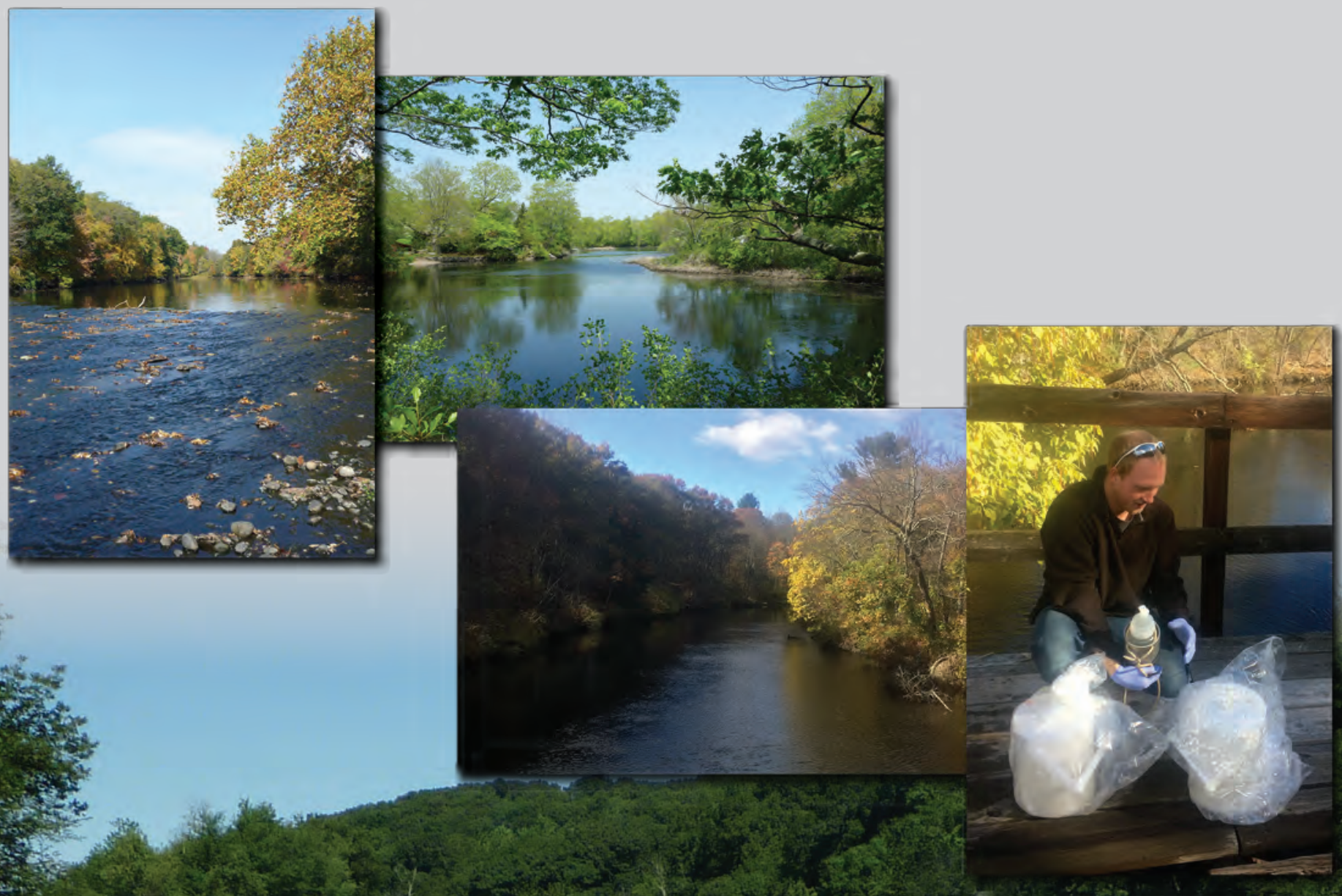

Scientific Investigations Report 2016-5178 


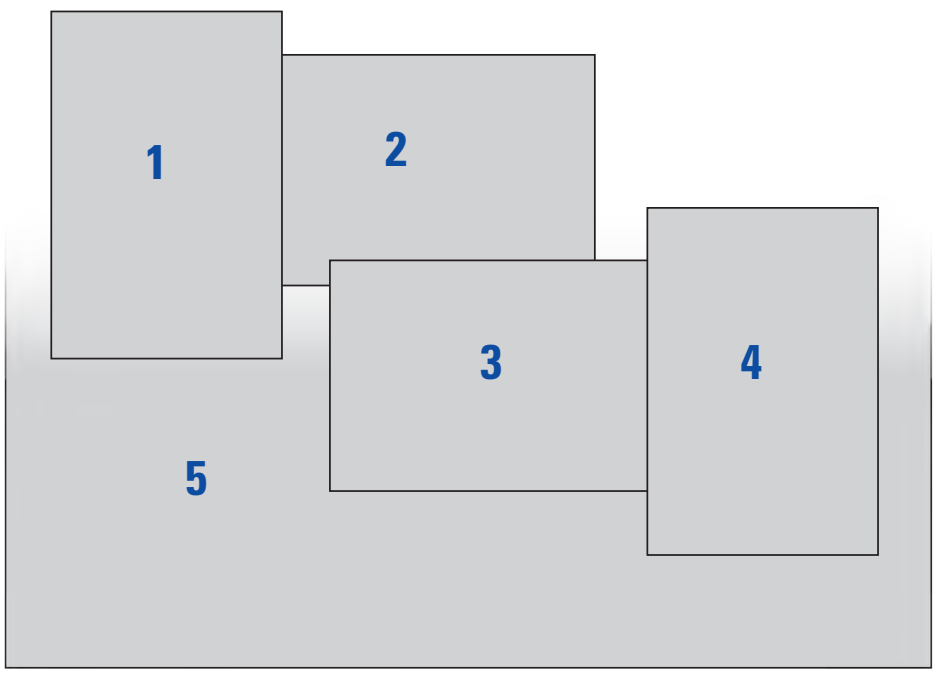

Cover. 1. Blackstone River near Quinville Conservation Area, Lincoln, Rhode Island, 2. Pawcatuck River near Nooseneck Hill Road, Westerly, Rhode Island, 3. Blackstone River at Millville, Massachusetts, 4. USGS hydrologic technician at Blackstone River at Millville, Massachusetts, 5. Dam on the Blackstone River at Albion Mills, Lincoln, Rhode Island. Photographs 1, 2, and 5 by the Rhode Island Department of Environmental Management.

Back cover. George Washington Highway and Blackstone River Bikeway bridges over the Blackstone River at the Captain Wilbur Kelly House Museum, Lincoln, Rhode Island. Photograph by the Rhode Island Department of Environmental Management. 


\section{Analysis of Trends of Water Quality and Streamflow in the Blackstone, Branch, Pawtuxet, and Pawcatuck Rivers, Massachusetts and Rhode Island, 1979 to 2015}

By Jennifer G. Savoie, John R. Mullaney, and Gardner C. Bent

Prepared in cooperation with

the Rhode Island Department of Environmental Management, the Rhode Island Water Resources Board, and the U.S. Environmental Protection Agency

Scientific Investigations Report 2016-5178 


\section{U.S. Department of the Interior SALLY JEWELL, Secretary}

\section{U.S. Geological Survey Suzette M. Kimball, Director}

\section{U.S. Geological Survey, Reston, Virginia: 2017}

For more information on the USGS - the Federal source for science about the Earth, its natural and living resources, natural hazards, and the environment-visit https://www.usgs.gov or call 1-888-ASK-USGS.

For an overview of USGS information products, including maps, imagery, and publications, visit https://store.usgs.gov.

Any use of trade, firm, or product names is for descriptive purposes only and does not imply endorsement by the U.S. Government.

Although this information product, for the most part, is in the public domain, it also may contain copyrighted materials as noted in the text. Permission to reproduce copyrighted items must be secured from the copyright owner.

Suggested citation:

Savoie, J.G., Mullaney, J.R., and Bent, G.C., 2017, Analysis of trends of water quality and streamflow in the Blackstone, Branch, Pawtuxet, and Pawcatuck Rivers, Massachusetts and Rhode Island, 1979 to 2015: U.S. Geological Survey Scientific Investigations Report 2016-5178, 43 p, https://doi.org/10.3133/sir20165178.

ISSN 2328-031X (print) ISSN 2328-0328 (online) ISBN 978-1-4113-4102-9 


\section{Contents}

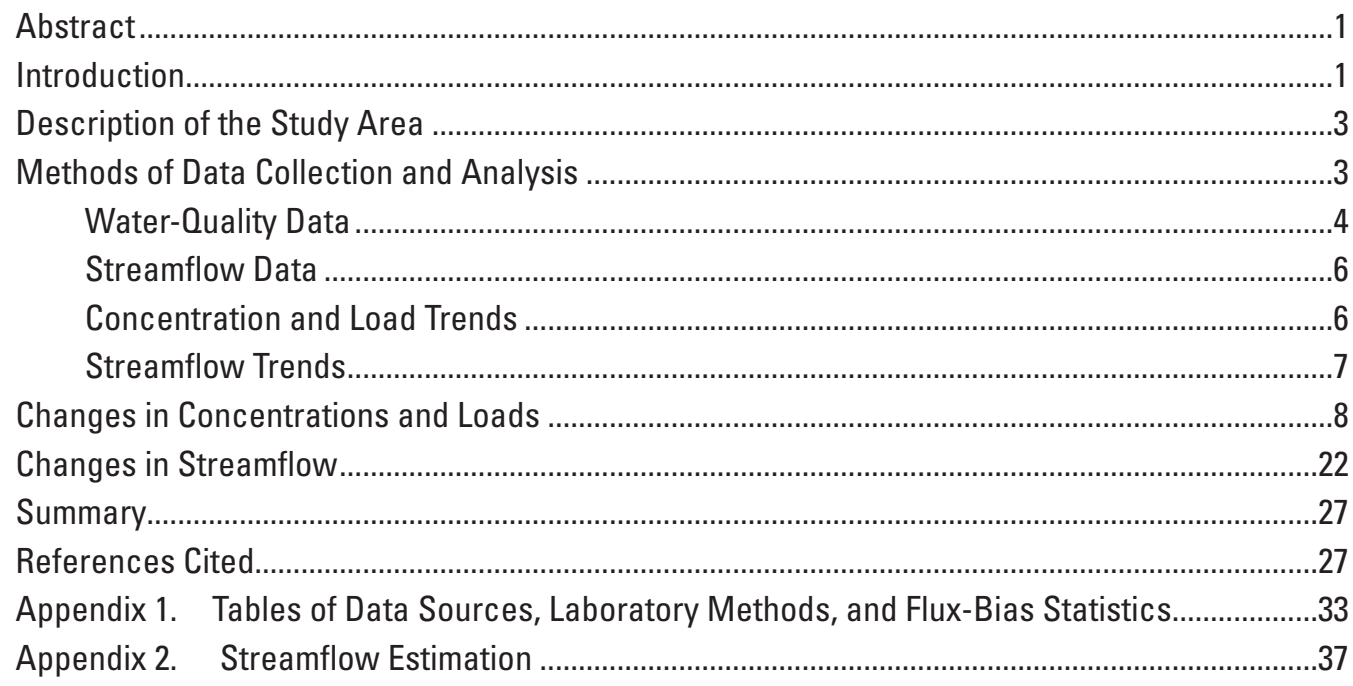

\section{Figures}

1. Map showing Blackstone, Pawtuxet, and Pawcatuck River Basin boundaries, streamgages and partial-record stations, and water-quality-monitoring stations on the Blackstone, Branch, Pawtuxet, and Pawcatuck Rivers in Massachusetts and Rhode Island

2. Time-series plots of total nitrogen concentrations in the Branch, Blackstone, Pawtuxet, and Pawcatuck Rivers in Massachusetts and Rhode Island, 1979 through 2015 (2007 through 2015 for Blackstone River at Pawtucket).

3. Time-series plots of nitrite plus nitrate concentrations in the Branch, Blackstone, Pawtuxet, and Pawcatuck Rivers in Massachusetts and Rhode Island, 1979 through 2015 (2007 through 2015 for Blackstone River at Pawtucket, and 1979 through 2014 for Blackstone River at Millville).

4. Time-series plots of total phosphorus concentrations in the Branch, Blackstone, Pawtuxet, and Pawcatuck Rivers in Massachusetts and Rhode Island, 1979 through 2015 (2007 through 2015 for Blackstone River at Pawtucket).

5. Time-series plots of chloride concentrations in the Branch, Blackstone, Pawtuxet, and Pawcatuck Rivers in Massachusetts and Rhode Island, 1979 through 2015 (2007 through 2015 for Blackstone River at Pawtucket)..

6. Graphs showing 90-percent confidence bands for total nitrogen concentrations in the Branch, Blackstone, Pawtuxet, and Pawcatuck Rivers in Massachusetts and Rhode Island, 1979 through 2015 (2007 through 2015 for Blackstone River at Pawtucket).........13

7. Graphs showing 90-percent confidence bands for nitrite plus nitrate concentrations in the Branch, Blackstone, Pawtuxet, and Pawcatuck Rivers in Massachusetts and Rhode Island, 1979 through 2015 (1979 through 2014 for Blackstone at Millville, and 2007 through 2015 for Blackstone River at Pawtucket) ......14

8. Graphs showing 90-percent confidence bands for total phosphorus concentrations in the Branch, Blackstone, Pawtuxet, and Pawcatuck Rivers in Massachusetts and Rhode Island, 1979 through 2015 (2007 through 2015 for Blackstone River at Pawtucket) 
9. Graphs showing 90-percent confidence bands for chloride concentrations in the Branch, Blackstone, Pawtuxet, and Pawcatuck Rivers in Massachusetts and Rhode Island, 1979 through 2015 (2007 through 2015 for Blackstone River at Pawtucket).

10. Graphs showing 90-percent confidence bands for total nitrogen loads in the Branch, Blackstone, Pawtuxet, and Pawcatuck Rivers in Massachusetts and Rhode Island, 1979 through 2015 (2007 through 2015 for Blackstone River at Pawtucket).

11. Graphs showing 90-percent confidence bands for nitrite plus nitrate loads in the Branch, Blackstone, Pawtuxet, and Pawcatuck Rivers in Massachusetts and Rhode Island, 1979 through 2015 (1979 through 2014 for Blackstone at Millville, and 2007 through 2015 for Blackstone River at Pawtucket)

12. Graphs showing 90-percent confidence bands for total phosphorus loads in the Branch, Blackstone, Pawtuxet, and Pawcatuck Rivers in Massachusetts and Rhode Island, 1979 through 2015 (2007 through 2015 for Blackstone River at Pawtucket).

13. Graphs showing 90-percent confidence bands for chloride loads in the Branch, Blackstone, Pawtuxet, and Pawcatuck Rivers in Massachusetts and Rhode Island, 1979 through 2015 (2007 through 2015 for Blackstone River at Pawtucket).

14. Annual streamflow statistics (dots) of maximum day, mean daily, median daily, and 7-day minimum streamflow, and locally weighted scatterplot smooth (solid line) at the Branch River at Forestdale, Rhode Island (streamgage 01111500), 1979 through 2015 .

15. Annual streamflow statistics (dots) of maximum day, mean daily, median daily, and 7-day minimum streamflow, and locally weighted scatterplot smooth (solid line) at the Blackstone River at Woonsocket, Rhode Island (streamgage 01112500), 1979 through 2015

16. Annual streamflow statistics (dots) of the maximum day, mean daily, median daily, and 7-day minimum streamflow, and locally weighted scatterplot smooth (solid line) for the Pawtuxet River at Cranston, Rhode Island (streamgage 01116500), 1979 through 2015

17. Annual streamflow statistics (dots) of the maximum day, mean daily, median daily, and 7-day minimum streamflow, and locally weighted scatterplot smooth (solid line) for the Pawcatuck River at Westerly, Rhode Island (streamgage 01118500), 1979 through 2015

\section{Tables}

1. Location coordinates, drainage-basin areas, station types, and periods of records for streamflow- and water-quality-monitoring stations on the Blackstone, Branch, Pawtuxet, and Pawcatuck Rivers in Massachusetts and Rhode Island.

2. Changes and percent changes in flow-normalized concentrations and loads between water years 1979 and 2015 (2007 and 2015 for streamgage 01113895, and 1979 and 2014 for nitrite plus nitrate for streamgage 01111230) and probabilities of trends in concentration for selected constituents at water-quality-monitoring stations on the Blackstone, Branch, Pawtuxet, and Pawcatuck Rivers in Massachusetts and Rhode Island .

3. Percent changes in statistics between 1979 and 2015 at stations on the Branch, Blackstone, Pawtuxet, and Pawcatuck Rivers in Rhode Island 


\section{Conversion Factors}

International System of Units to U.S. customary units

\begin{tabular}{lcl}
\hline \multicolumn{1}{c}{ Multiply } & By & \multicolumn{1}{c}{ To obtain } \\
kilometer $(\mathrm{km})$ & 0.6214 & mile $(\mathrm{mi})$ \\
square kilometer $\left(\mathrm{km}^{2}\right)$ & 0.3861 & square mile $\left(\mathrm{mi}^{2}\right)$ \\
cubic meter per second $\left(\mathrm{m}^{3} / \mathrm{s}\right)$ & 35.31 & cubic foot per second $(\mathrm{ft} / \mathrm{s})$ \\
cubic meter per second $\left(\mathrm{m}^{3} / \mathrm{s}\right)$ & 22.83 & million gallons per day $(\mathrm{Mgal} / \mathrm{d})$ \\
kilogram per year $(\mathrm{kg} / \mathrm{yr})$ & 2.205 & pound per year $(\mathrm{lb} / \mathrm{yr})$ \\
\hline
\end{tabular}

\section{Datum}

Horizontal coordinate information is referenced to the North American Datum of 1983 (NAD 83).

\section{Supplemental Information}

Concentrations of chemical constituents in water are given in milligrams per liter (mg/L).

\section{Abbreviations}

$\begin{array}{ll}\text { EGRET } & \text { Exploration and Graphics for RivEr Trends package } \\ \text { EGRETci } & \text { Exploration and Graphics for RivEr Trends Confidence Intervals package } \\ \mathrm{N} & \text { nitrogen } \\ \mathrm{NO}_{2}+\mathrm{NO}_{3} & \text { nitrite plus nitrate } \\ \mathrm{NWIS} & \text { National Water Information System } \\ \mathrm{PC} & \text { parameter code } \\ \text { RIDEM } & \text { Rhode Island Department of Environmental Management } \\ \text { TN } & \text { total nitrogen } \\ \text { TP } & \text { total phosphorus } \\ \text { TPN } & \text { total particulate nitrogen } \\ \text { USGS } & \text { U.S. Geological Survey } \\ \text { WBT } & \text { WRTDS Bootstrapping Test } \\ \text { WRTDS } & \text { Weighted Regressions on Time, Discharge, and Season }\end{array}$





\title{
Analysis of Trends of Water Quality and Streamflow in the Blackstone, Branch, Pawtuxet, and Pawcatuck Rivers, Massachusetts and Rhode Island, 1979 to 2015
}

\author{
By Jennifer G. Savoie, John R. Mullaney, and Gardner C. Bent
}

\section{Abstract}

Trends in long-term water-quality and streamflow data from six water-quality-monitoring stations within three major river basins in Massachusetts and Rhode Island that flow into Narragansett Bay and Little Narragansett Bay were evaluated for water years 1979-2015. In this study, conducted by the U.S. Geological Survey in cooperation with the Rhode Island Department of Environmental Management, the Rhode Island Water Resources Board, and the U.S. Environmental Protection Agency, water-quality and streamflow data were evaluated with a Weighted Regressions on Time, Discharge, and Season smoothing method, which removes the effects of year-toyear variation in water-quality conditions due to variations in streamflow (discharge). Trends in annual mean, annual median, annual maximum, and annual 7-day minimum flows at four continuous streamgages were evaluated by using a time-series smoothing method for water years 1979-2015.

Water quality at all monitoring stations changed over the study period. Decreasing trends in flow-normalized nutrient concentrations and loads were observed during the period at most monitoring stations for total nitrogen, nitrite plus nitrate, and total phosphorus. Average flow-normalized loads for water years 1979-2015 decreased in the Blackstone River by up to 46 percent in total nitrogen, 17 percent in nitrite plus nitrate, and 69 percent in total phosphorus. The other rivers also had decreasing flow-normalized trends in nutrient concentrations and loads, except for the Pawtuxet River, which had an increasing trend in nitrite plus nitrate. Increasing trends in flow-normalized chloride concentrations and loads were observed during the study period at all of the rivers, with increases of more than 200 percent in the Blackstone River.

Small increasing trends in annual mean daily streamflow were observed in 3 of the 4 rivers, with increases of 1.2 to 11 percent; however, the trends were not significant. All 4 rivers had decreases in streamflow for the annual 7-day minimums, but only 3 of the 4 rivers had decreases that were significant (34 to 54 percent). The Branch River had decreasing annual mean daily streamflow ( 7.5 percent) and the largest decrease in the annual 7-day minimum streamflow. The Blackstone and Pawtuxet Rivers had the largest increases in annual maximum daily flows but had decreases in the annual 7-day minimum flows.

\section{Introduction}

Long-term monitoring data are essential to determine how ecosystems and water resources respond to natural and anthropogenic changes. The U.S. Geological Survey (USGS), in cooperation with the Rhode Island Department of Environmental Management (RIDEM) and the Rhode Island Water Resources Board, has monitored streamflow and collected water-quality data at six water-quality-monitoring stations on the Blackstone, Branch, Pawtuxet, and Pawcatuck River Basins in Massachusetts and Rhode Island (fig. 1; Branch River Basin not shown) since 1979 (except for a 4-year period from water years ${ }^{1} 2003$ through 2006 when water-quality samples were not collected). Data collection included monthly to quarterly measurements of physical properties, cations, anions, metals, and nutrients. During this time, the region underwent many changes and the population in Rhode Island increased about 10 percent (U.S. Census Bureau, 2015). In the study area, domestic and public-supply wells withdraw water for domestic and commercial purposes from surface-water and groundwater sources, and municipal wastewater-treatment facilities and domestic septic systems discharge to or near the rivers. Water-supply wells generally withdraw water from

\footnotetext{
${ }^{1}$ In this report years are given as water years. A water year is defined as the 12-month period from October 1 through September 30 and is designated by the calendar year in which it ends.
} 


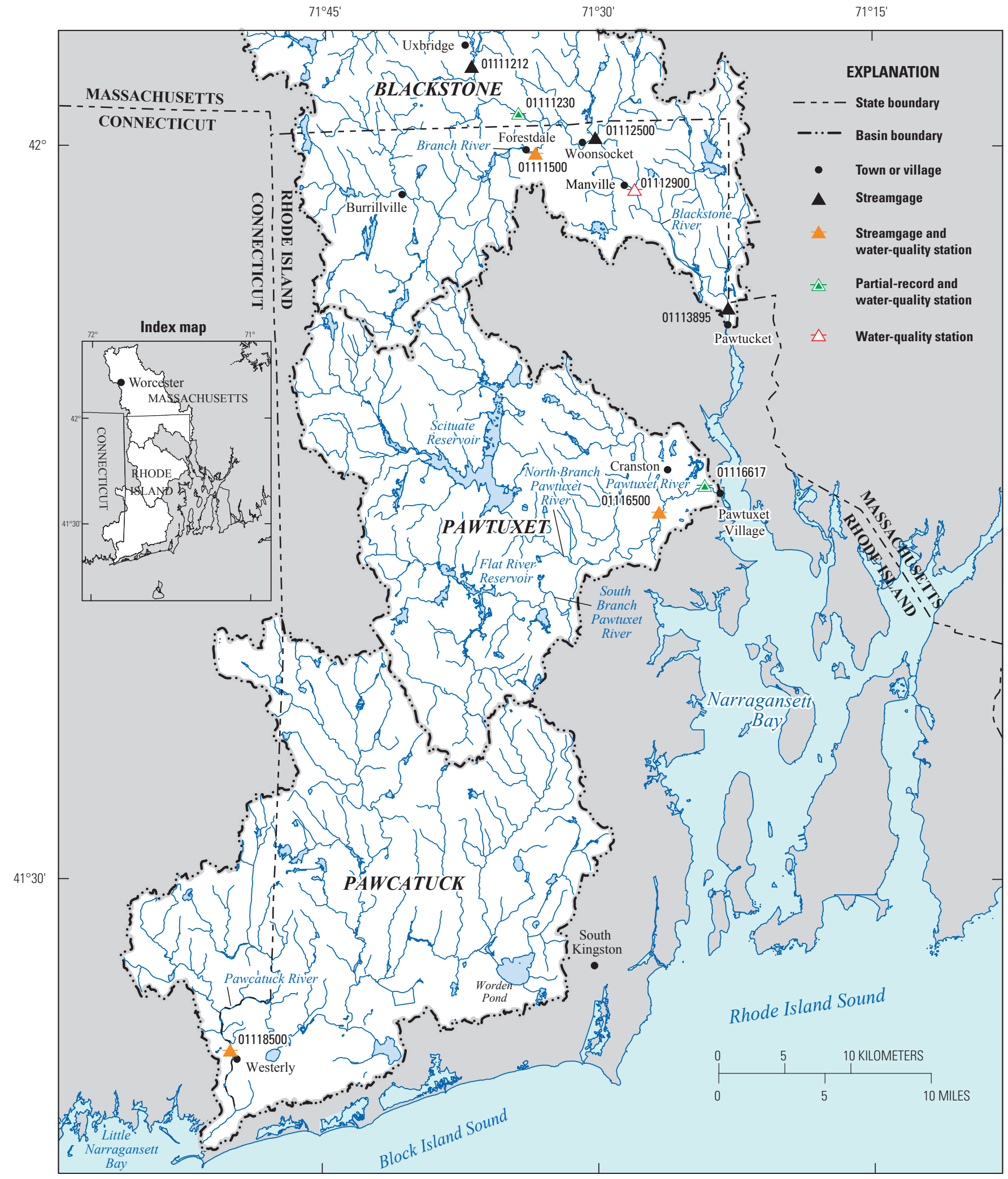

Base from ESRI, Delorme, NOAA, NGDC, and other contributors of digital data Rhode Island State Plane projection

Figure 1. Blackstone, Pawtuxet, and Pawcatuck River Basin boundaries, streamgages and partial-record stations, and water-qualitymonitoring stations on the Blackstone, Branch, Pawtuxet, and Pawcatuck Rivers in Massachusetts and Rhode Island. See table 1 for station names. 
shallow sand and gravel aquifers that are in direct hydraulic connection with the rivers, ponds, and wetlands (Barbaro and Zarriello, 2007). The RIDEM manages Rhode Island's water resources by authorizing withdrawal permits and by implementing programs and policies to protect the water quality and supply of the State's surface-water, groundwater, and wetlands resources.

The Blackstone and Pawtuxet Rivers flow into Narragansett Bay and together drain large parts of central Massachusetts and Rhode Island. The Blackstone and Pawtuxet River Basins have a long history of human activities that affect streamflow and water quality. The Blackstone River, described as "America's hardest working river," was the first location in America to harness water power for use in textile mills with the construction of the Slater Mill in Pawtucket, Rhode Island, in 1791 (Klyberg, 2012). Soon to follow were more mills in the Blackstone and Pawtuxet River Basins and related infrastructure such as dams, mill ponds, canals, railroads, and towns that altered the landscape, natural flow, and ecosystem of these rivers (Blackstone River Valley National Heritage Corridor Commission, 1998). Dams owned by States, municipalities, and private landowners continue to alter the natural flow of many of the rivers.

The Pawcatuck River flows into Little Narraganset Bay and drains a large part of south-central Rhode Island and eastern Connecticut. Most of the Pawcatuck River Basin is considered to have high-quality water, and water in the basin is used primarily for public supply and irrigation (Breault and others, 2009). However, the estuarine part of the river, near Westerly, R.I., and Little Narraganset Bay, is considered to be a nitrogen-enriched system and has experienced loss of eelgrass and excessive macroalgae growth (Fulweiler and Nixon, 2005).

Water quality and ecology in Narragansett Bay and surrounding basins have been extensively studied by universities, State and local government agencies, nongovernmental organizations, and other stakeholders. Significant efforts have been made to improve water-quality conditions in the rivers and bay, particularly with respect to nutrients and metals. Sources of information on assessments of chemical input into Narragansett Bay and improvements of infrastructure, including a book by Desbonnet and Costa-Pierce (2008) and numerous reports and other publications about the history of water-quality status and improvements in infrastructure, can be found on the RIDEM Web site (Rhode Island Department of Environmental Management, 2016).

The USGS, in cooperation with the U.S. Environmental Protection Agency, analyzed the trends in water-quality and streamflow data from water-quality-monitoring stations on the Blackstone, Branch, Pawtuxet, and Pawcatuck Rivers from October 1, 1978, through September 30, 2015. This report presents the results of the analysis, which evaluated long-term trends in total nitrogen, nitrite plus nitrate, total phosphorus, and chloride data using the Weighted Regressions on Time, Discharge, and Season (WRTDS) method developed by Hirsch and others (2010). Also presented is an analysis of long-term changes in river flow at four long-term streamgages in the basins; this analysis was made by using the Exploration and Graphics for RivEr Trends (EGRET) R package (Hirsch and De Cicco, 2015).

\section{Description of the Study Area}

The Blackstone River Basin is located in central Massachusetts and northern Rhode Island and comprises an area of 1,230 square kilometers $\left(\mathrm{km}^{2}\right.$; fig. 1). The Blackstone River originates near Worcester, Massachusetts, and flows south 124 kilometers $(\mathrm{km})$ through several towns in Massachusetts before passing through Woonsocket and Pawtucket, R.I., and discharging into Narragansett Bay. The Blackstone River is listed as impaired by the RIDEM with respect to bacteria and trace metals (Rhode Island Department of Environmental Management, 2013). The Branch River Basin (not shown in fig. 1) comprises $236 \mathrm{~km}^{2}$ within the Blackstone River Basin and originates in Burrillville, R.I., from which the river flows about $26 \mathrm{~km}$ east and joins the Blackstone River in Forestdale, R.I. The Pawtuxet River Basin is located in central Rhode Island and comprises an area of $596 \mathrm{~km}^{2}$. The Pawtuxet River originates at the confluence of the North Branch of the Pawtuxet River, which flows from the Flat River Reservoir, and the South Branch of the Pawtuxet River, which flows from the Scituate Reservoir. The Pawtuxet River generally flows east about $32 \mathrm{~km}$ and flows into Narragansett Bay near Pawtuxet Village, R.I. The Pawcatuck River Basin is located in southern Rhode Island and eastern Connecticut and comprises an area of $764 \mathrm{~km}^{2}$. The Pawcatuck River originates at Worden Pond in South Kingston, R.I., flows west and south $88 \mathrm{~km}$, and discharges into Little Narragansett Bay at the border of Rhode Island and Connecticut near the town of Westerly, R.I.

\section{Methods of Data Collection and Analysis}

Water-quality data on nitrogen, phosphorus, and chloride and streamflow data were analyzed for six water-qualitymonitoring stations in Massachusetts and Rhode Island by using EGRET, which runs in the R statistical environment (https://www.r-project.org/). The EGRET package contains a Weighted Regressions on Time, Discharge, and Season (WRTDS) module for analysis of concentrations and constituent loads as well as flow-normalized concentrations and loads. Flow normalization is an important part of the analysis of trends because it removes the variation in water-quality conditions that arises because of variations in streamflow. Without the use of flow normalization, the underlying changes in water quality are often obscured by the year-to-year variations that arise because of a particularly wet or dry year. The EGRET 
package also contains a flow history module for graphical analysis of long-term trends in streamflow. The flow history analysis was used to evaluate trends in annual mean, annual median, annual maximum daily, and annual 7-day minimum streamflow for the study period.

The water-quality and streamflow data were retrieved from the USGS National Water Information System (NWIS) database (U.S. Geological Survey, 2016). Three of the six water-quality-monitoring stations did not have streamgages at the water-quality-monitoring station, and in these cases, nearby streamgages were used to estimate streamflow. A near-complete record of water-quality data from October 1 , 1978, to September 30, 2015, was retrieved for two waterquality-monitoring stations on the Blackstone River (USGS streamgages 01111230 and 01112900), one station on the Branch River (USGS streamgage 01111500), one station on the Pawtuxet River (USGS streamgage 01116617), and one station on the Pawcatuck River (USGS streamgage 01118500). Samples were not collected at these stations for 2003-6. Streamflow data were retrieved from NWIS for streamgages 01111500 and 01118500 , and streamflow was estimated for streamgages 01111230,01112900 , and 01116617 by using partial records and (or) nearby streamgages. Water-quality and streamflow data from 2007 through 2015 were retrieved from NWIS for the Blackstone River at Roosevelt Street at Pawtucket, R.I. (01113895) streamgage. The six waterquality-monitoring stations represent four rivers within three drainage basins that discharge into Narragansett Bay and Little Narragansett Bay (fig. 1; table 1). Water-quality datasets were retrieved from NWIS, and some data were modified as follows. Flow-weighted composite samples, collected for another study, were removed, as they were not appropriate for use with the WRTDS method. If multiple samples were collected on the same day, the mean value for the constituent was used in the analyses. Samples with high total nitrogen concentrations (greater than 10 milligrams per liter $[\mathrm{mg} / \mathrm{L}]$ ) and high nitrite plus nitrate concentrations (greater than $5 \mathrm{mg} / \mathrm{L}$ as nitrogen $[\mathrm{N}]$ ) were considered extreme outliers and not used in the analyses. Information on sources of measured, estimated, and simulated data used for analysis of streamflow and water quality are included in appendix 1, table 1-1.

\section{Water-Quality Data}

Methods of laboratory analyses of total nitrogen, nitrite plus nitrate, total phosphorus, and chloride concentrations varied throughout the study period and are summarized in appendix 1, table 1-2.

The method of analysis for total nitrogen (TN) had the most changes throughout the study period:

- October 1978 through August 2002 TN concentrations (USGS parameter code [PC] 00600) were calculated by the sum of concentrations of total ammonia plus organic nitrogen (USGS PC 00625, mg/L as N) measured using the Kjeldahl analysis method (Fishman and Friedman, 1989; Patton and Truitt, 2000) and nitrite plus nitrate (USGS PC 00631, or 00630, $\mathrm{mg} / \mathrm{L}$ as N) measured using colorimetric determination method (Fishman and Friedman, 1989; Fishman, 1993).

- September 2002 through February 2007: TN samples were not collected because of a temporary loss in funding.

- February 2007 through January 2013: TN concentrations (USGS PC 62855) were analyzed by using the alkaline persulfate digestion method (Patton and Kryskalla, 2003).

- January 2013 through September 2015, three different TN methods of analysis were used:

1. TN concentrations (USGS PC 62855) analyzed using the alkaline persulfate digestion method (Patton and Kryskalla, 2003)

2. TN concentrations calculated by adding concentrations of total dissolved nitrogen (TDN, USGS PC 62854), analyzed using the alkaline persulfate digestion method, and total particulate nitrogen (TPN, USGS PC 49570), analyzed using the high-temperature-combustion method (Zimmerman and others, 1997)

3. TN concentrations calculated by adding concentrations of total ammonia plus organic nitrogen (USGS PC 00625, mg/L as N), analyzed using the Kjeldahl digestion method, and nitrite plus nitrate (USGS PC 00631, mg/L as N), analyzed using colorimetric determination method (Patton and Kryskalla, 2011)

For samples on dates when more than one TN analytical results were available, the TDN (USGS PC 62854) plus TPN (USGS PC 49570) concentration was used to represent TN, unless the TPN value was less than the method detection limit. When TPN values were less than the method detection limit, the total ammonia plus organic nitrogen (USGS PC 00625, $\mathrm{mg} / \mathrm{L}$ as $\mathrm{N}$ ) plus nitrite plus nitrate (USGS PC 00631, $\mathrm{mg} / \mathrm{L}$ as $\mathrm{N}$ ) concentration was used to represent $\mathrm{TN}$.

To evaluate the potential bias created by these laboratory method changes, TN data for the period of 2013-15 were compared, as all three TN methods were used during that period. The average differences in TN concentrations, as well as the relative percent differences, were evaluated between TN $(00625+00631)$ and TN (62855) and between $\mathrm{TN}(00625+00631)$ and $\mathrm{TN}(62854+49570)$. In addition, the difference between TN $(62855)$ and TN $(62854+49570)$ was determined (appendix 1, table 1-3).

The average difference between TN $(00625+00631)$ and TN (62855) was the largest, averaging $0.058 \mathrm{mg} / \mathrm{L}$, 


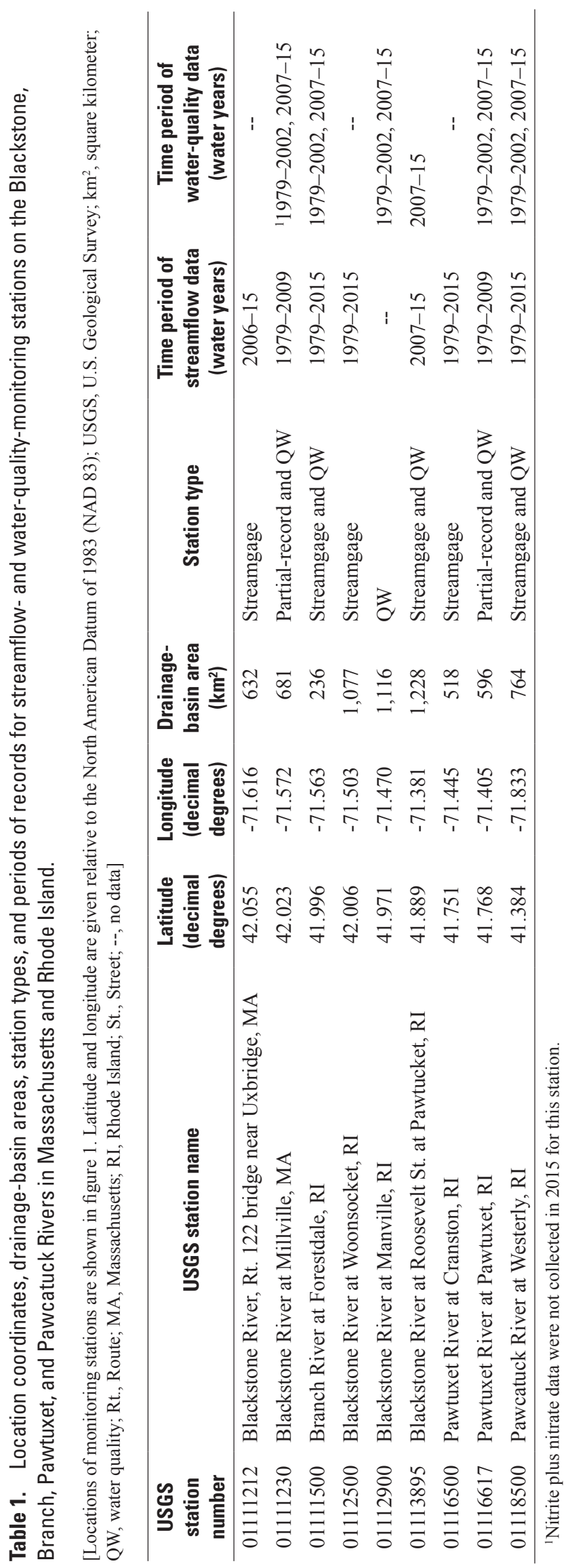


or 5.32 percent, indicating that concentrations of TN from 2007 to early 2013 were likely biased low relative to TN $(00625+00631)$ data collected prior to 2007. This difference is small relative to the concentrations measured at the monitoring stations in this report, and it should have minimal influence on the observed trends in TN.

Both the Kjeldahl and alkaline persulfate digestions methods are considered to have some bias (Rus and others, 2012), and the USGS recommended method (U.S. Geological Survey, 2013) for acquisition of TN data, as of 2013, is to use alkaline persulfate digestion to analyze TN (62854) along with TPN (49570). The average difference between TN (00625+ $00631)$ and $\mathrm{TN}(62854+49570)$ was $0.030 \mathrm{mg} / \mathrm{L}$, or 2.55 percent, indicating that data collected prior to 2007 and intermittent data collected from 2013 to 2015 (if 49570 was below detection) were biased high relative to the newest USGS recommended method. The differences are small and should have little or no effect on the observed trends in concentrations and loads.

The difference between TN (62855) and TN $(62854+$ 49570) was $-0.029 \mathrm{mg} / \mathrm{L}$, or -2.97 percent, indicating that data collected from 2007 to early 2013 were biased low relative to the USGS recommended method; however, this difference is small relative to the concentrations in the samples in this study and should have minimal influence on the observed trends.

Concentrations of nitrite plus nitrate $\left(\mathrm{NO}_{2}+\mathrm{NO}_{3}\right)$ from 1978 until 1993 were analyzed by using an unfiltered sample (Fishman and Friedman, 1989, USGS PC 00630), and from 1993 onward by using a filtered sample (Patton and Kryskalla, 2011, USGS PC 00631). The change from unfiltered to filtered preservation was administered by the USGS National Water Quality Laboratory, and studies have shown minimal difference between filtered and unfiltered concentrations for $\mathrm{NO}_{2}+\mathrm{NO}_{3}$ samples (Fishman and Friedman, 1989; Goolsby and Battaglin, 2001). Total phosphorus (TP) concentrations (USGS PC 00665) and chloride concentrations (USGS PC 00940) were analyzed by multiple laboratory methods over time (appendix 1, table 1-2). The final concentration datasets used for this study are available upon request from the USGS New England Water Science Center.

\section{Streamflow Data}

Streamflow data from three water-quality-monitoring stations with continuous measurement of streamflow (USGS streamgages 01111500,01113895 , and 01118500; fig. 1; table 1) were retrieved from the NWIS database (U.S. Geological Survey, 2016). The other three water-quality-monitoring stations (USGS streamgages 01111230, 01112900, and 01116617) had incomplete records or no continuous streamflow data, so the daily streamflow values for the period of record were estimated. Estimates of daily mean streamflow or streamflow statistics often are needed at monitoring stations that are ungaged but that have miscellaneous streamflow measurements over at least a few years. These stations are often referred to as partial-record stations. Through correlation and streamflow-record extension techniques, daily mean streamflow and (or) statistics for partial-record stations can be estimated. Estimates can be made on the basis of the relation between the miscellaneous streamflow measurements at the partial-record station and the concurrent daily mean streamflows at nearby streamgages. Additionally, for stations with no physical streamflow measurements and a streamgage located nearby (upstream or downstream) on the same river reach, estimates of daily mean streamflow can be made by using the drainage-area-ratio method. Details on streamflow estimation for streamgages 01111230,01112900 , and 01116617 are provided in appendix 2, and estimated values used in this study are available upon request from the USGS New England Water Science Center.

\section{Concentration and Load Trends}

The WRTDS smoothing method is based on the work of Hirsch and others (2010). WRTDS was designed to interpret the behavior of the water-quality analyte of interest on the basis of four components: the relation to streamflow, seasonality, long-term trend, and a random component. This analysis produces tabular and graphical representations of the concentration and the load of the analyte as it relates to these driving factors. WRTDS presents annual and seasonal summaries of the behavior of concentration and load over time and flow-normalized estimates of concentration and load that are designed to remove the influence of year-to-year variations in streamflow and thus provide more insight on underlying changes in the behavior of the watershed (Hirsch and De Cicco, 2015). A load represents the mass of substance that passes the sampling location in a given period of time and incorporates the variability of concentration and the hydrologic system during the period of sample collection

The WRTDS method creates a highly flexible statistical representation of the expected value of concentration for every day in the period of record and then uses that representation to produce four daily time series for the period of record. These are daily concentration, daily load, flow-normalized daily concentration, and flow-normalized daily load. The flow-normalized values are intended to describe the changing state of the system over time, by integrating out the influences of variations in concentration or load that arise from the day-to-day variations in streamflow. In contrast, the non-flow-normalized versions of these variables are estimates of what actually happened on each day and, as such, they are highly influenced by the actual streamflow of that day (Hirsch and De Cicco, 2015).

Application of the WRTDS model with data from the Blackstone, Branch, Pawtuxet, and Pawcatuck Rivers was run with the following default settings, described in Hirsch and De Cicco (2015): 
- windowY: the half window width for the time weighting (set to 7 years)

- windowQ: the half window width for the weighting in terms of $\ln$ (discharge) (set to 2 )

- windowS: the half window width for the seasonal weighting, measured in years (set to 0.5 )

Some regression models for load estimation produce biased estimates of loads, as described by Stenback and others (2011) and Hirsch (2014). In this section of the report, the term "flux" is synonymous with load. WRTDS produces a flux-bias statistic. The flux-bias statistic in WRTDS is a dimensionless representation of the difference between the sum of the estimated fluxes on all sampled days and the sum of the true fluxes on all sampled days. A value near zero suggests that the model is nearly unbiased. A positive value suggests a positive bias, and a negative value suggests a negative bias. Values between -0.1 and +0.1 indicate that the bias in estimates of the long-term mean flux is likely to be less than 10 percent. The flux-bias statistic is useful for identifying problem datasets that might require a different load modeling approach. Flux-bias statistics for each monitoring station and constituent analyzed were 4 percent or less except for TP in the Branch River, which was 22 percent (appendix 1, table 1-4).

At the stations with long-term data analyzed for this study (all stations except Blackstone River at Roosevelt Street at Pawtucket, R.I.), water-quality data were not collected during 2003-6. This missing period of record was removed from the WRTDS analyses by using the EGRET function blankTime, as the load and concentration estimates produced during this period are likely to be unreliable.

In order to quantify the uncertainty in the direction and likelihood of trends, the WRTDS Bootstrapping Test (WBT), developed by Hirsch and others (2015), was used on the results from the WRTDS analyses for each site and constituent. The WBT analysis is available on the R package EGRETci that runs in the $\mathrm{R}$ statistical environment (https://www.r-project.org/). The estimate of trend in flownormalized concentration or load between any two years is a standard output of the existing WRTDS procedure. The WBT determines, using a block bootstrap method, a 90-percent confidence interval on the magnitude of that trend in flow-normalized load or concentration. The WBT then decides whether to reject the null hypothesis that the trend in the expected value of flow-normalized load or concentration is zero (Hirsch and others, 2015). The WBT is a type of block bootstrap that has the effect of approximately maintaining the short-term serial correlation structure that exists in the dataset without having to attempt to model that serial correlation structure. This method is used because residuals from WRTDS models tend to have runs of positive or negative values that persist for several days to several weeks. The WBT uses a time-based block bootstrap that was developed out of concerns about highly unequal sampling frequencies that are common to water-quality records with long-time periods and intermittent sampling. These hypothesis tests were run with the following settings in EGRETci:

- $\mathrm{nBoOt}$, the maximum number of bootstrap replicates, $=200$

- bootBreak, the minimum number of bootstrap replicates, $=100$

- blockLength, the length of the time blocks in the bootstrap analysis, $=200$ days

- confStop, the width of the confidence interval used in adaptive stopping rule, $=0.7$

Discussions on the selection of these values are given in Hirsch and others (2015).

The probability of a trend is described by the following descriptors from Hirsch and others (2015, table 2) as a function of the posterior mean estimate of the probability of an increasing trend:

- $\geq 0.95$ and $\leq 1.0$, highly likely

- $\geq 0.90$ and $<0.95$, very likely

- $\geq 0.66$ and $<0.90$, likely

- $>0.33$ and $<0.66$, about as likely as not

- $>0.1$ and $\leq 0.33$, unlikely

- $>0.05$ and $\leq 0.1$, very unlikely

- $\geq 0$ and $\leq 0.05$, highly unlikely

In addition to the hypothesis testing, the WBT methodology was used to produce 90-percent confidence bands around the estimates of flow-normalized concentrations and loads. This was done by running WBT using $\mathrm{nBOOt}=100$ for every year in the record, which gives 100 replicates for each year for the flow-normalized load or concentration. The upper and lower bounds for each year are computed by ranking those 100 values and then by interpolating the 5-percent and 95-percent quantiles of the sample cumulative distribution function (Hirsch and others, 2015). Further description of the operation of EGRETci is given by Hirsch and De Cicco (2016). Output data on flow-normalized concentrations and loads from this study are archived and available upon request from the USGS New England Water Science Center.

\section{Streamflow Trends}

Flow history analyses were performed by using a timeseries smoothing method that is described in Hirsch and De Cicco (2015) and Mullaney (2016). This smoothing method is designed to analyze long flow records (greater than 30 years). The smoothing method can be used to analyze up to eight different streamflow statistics for annual or seasonal data; the statistics include minimum flows, median daily flows, mean 
daily flows, and maximum flows. After computing annual time series of these eight statistics, flow history analysis also produces a smoothed version of each time series, which emphasizes the broad, multiyear variations and changes in the central tendencies of the time series (Hirsch and De Cicco, 2015). In this study, we analyzed changes to the annual mean, annual median, annual maximum, and annual 7-day minimum flows. Statistical significance of the annual value of four selected discharge statistics was evaluated by using a Mann-Kendall test (Helsel and Hirsch, 2002).

Changes in annual mean and median flows are influential in computation of constituent loads. Load is likely to increase with flow since load is a product of flow and concentration, but concentrations of some particle-associated parameters commonly increase with flow because of resuspension of bed materials and mobilization of particles from the land surface during overland flow. Total phosphorus is a constituent that tends to be mobilized during high-flow events that cause high turbidity or sediment load; therefore, storm event and annual loads of total phosphorus are often related to the highest discharges in any year.

The annual 7-day minimum flow is the minimum 7-day mean of the daily mean streamflows. Streamflow changes are important in determining constituent concentrations in streams with significant treated wastewater contributions, as changes in flows represent the potential dilution of the concentration of a constituent, such as phosphorus, that can be related to the productivity and eutrophic status of a stream. Waste-discharge permits are commonly set on the basis of low-flow statistics because the effects of point sources on water quality are typically greatest at times of low flow. Output data on streamflow statistics from this study are archived and available upon request from the USGS New England Water Science Center.

\section{Changes in Concentrations and Loads}

Monthly concentrations of $\mathrm{TN}, \mathrm{NO}_{2}+\mathrm{NO}_{3}$, TP, and chloride for samples collected during 1979 through 2015 (2007 through 2015 for monitoring station 01113895) are shown in figures 2 through 5 . Total nitrogen concentrations generally ranged from 0.3 to $2 \mathrm{mg} / \mathrm{L}$ in the Branch and Pawcatuck Rivers and 0.3 to $6 \mathrm{mg} / \mathrm{L}$ in the Blackstone and Pawtuxet Rivers (fig. 2). Nitrite plus nitrate concentrations generally ranged from 0.2 to $3 \mathrm{mg} / \mathrm{L}$ as $\mathrm{N}$ in the Blackstone and Pawtuxet Rivers and were less than $1 \mathrm{mg} / \mathrm{L}$ as $\mathrm{N}$ in the Branch and Pawcatuck Rivers (fig. 3). Total phosphorus concentrations generally were less than $0.1 \mathrm{mg} / \mathrm{L}$ in the Branch and Pawcatuck Rivers, less than $1.5 \mathrm{mg} / \mathrm{L}$ in the Pawtuxet River, and less than $1 \mathrm{mg} / \mathrm{L}$ in the Blackstone River (fig. 4). Chloride concentrations generally ranged between about 20 to $150 \mathrm{mg} / \mathrm{L}$ on the Blackstone River, 10 to $50 \mathrm{mg} / \mathrm{L}$ on the Branch River, 20 to $100 \mathrm{mg} / \mathrm{L}$ on the Pawtuxet River, and 8 to $30 \mathrm{mg} / \mathrm{L}$ on the Pawcatuck River (fig. 5).
Annual estimated flow-normalized concentrations and loads of TN, $\mathrm{NO}_{2}+\mathrm{NO}_{3}$, TP, and chloride were calculated for three water-quality-monitoring stations on the Blackstone River for 1979 through 2015 (except for the Blackstone River at Roosevelt Street at Pawtucket, R.I., for which only data from 2007 through 2015 were included, and the Blackstone River at Millville, Mass., for which $\mathrm{NO}_{2}+\mathrm{NO}_{3}$ data only from 1979 through 2014 were included) and one water-quality-monitoring station on each of the Branch, Pawtuxet, and Pawcatuck Rivers (figs. 6 through 9, flow-normalized concentrations; and figs. 10 through 13, flow-normalized loads).

The annual estimated flow-normalized concentrations and loads between 1979 and 2015 for $\mathrm{TN}, \mathrm{NO}_{2}+\mathrm{NO}_{3}$, and TP (figs. $6-8,10-12)$ generally show a decreasing pattern at all monitoring stations with the exception of $\mathrm{NO}_{2}+\mathrm{NO}_{3}$ in the Pawtuxet River, where concentrations and loads increased. In the Blackstone River, from about 1992 to 2002, TN, $\mathrm{NO}_{2}+\mathrm{NO}_{3}$, and TP flow-normalized concentrations and loads increased; however, when sampling resumed in February 2007, flow-normalized concentrations and loads had a decreasing pattern. A comparison of flow-normalized nutrient loads between 1979 and 2015 for the Blackstone River shows decreases by up to 46 percent in TN, 17 percent in $\mathrm{NO}_{2}+\mathrm{NO}_{3}$, and 69 percent in TP (table 2). The probability of a decreasing trend in flow-adjusted nutrient concentrations and loads in the Blackstone River was "highly likely" and "very likely" based on the convention used by Hirsch and others (2015), indicating a significant trend at this station.

The Branch, Pawtuxet, and Pawcatuck Rivers had decreases in flow-adjusted nutrient concentrations and loads, with the exception that the Pawtuxet River had an increase in concentrations and loads ( 82 and 88 percent, respectively) of $\mathrm{NO}_{2}+\mathrm{NO}_{3}$. The decreasing trend in flow-adjusted nutrient concentrations and loads was significant, except at the Pawcatuck River, where decreasing trends of TN and $\mathrm{NO}_{2}+\mathrm{NO}_{3}$ concentrations were deemed "likely" (12 percent) and loads were "about as likely as not" (1.4 to 3.2 percent). Annual estimated flow-normalized concentrations and loads of chloride (figs. 9 and 13) increased at all locations between 1979 and 2015 and had a "highly likely" probability of increasing trends of more than 200 percent in the Blackstone River (increases of 84 and $69 \mathrm{mg} / \mathrm{L}$ at streamgages 01111230 and 01112900 , respectively), 160 percent in the Branch River, and 60 to 70 percent in the Pawtuxet and Pawcatuck Rivers, respectively.

Changes in concentrations and loads most likely reflect changes in source contributions within the basins, such as upgrades to wastewater-treatment facilities and deicing treatment of roads, as well as changes in land use and atmospheric deposition; however, identifying specific sources and the timing of source contributions and changes was beyond the scope of this study. Similar trends have been observed for nutrients and chloride in tributaries to Long Island Sound (Mullaney, 2016) and for chloride in other parts of the northern United States (Corsi and others, 2015). 


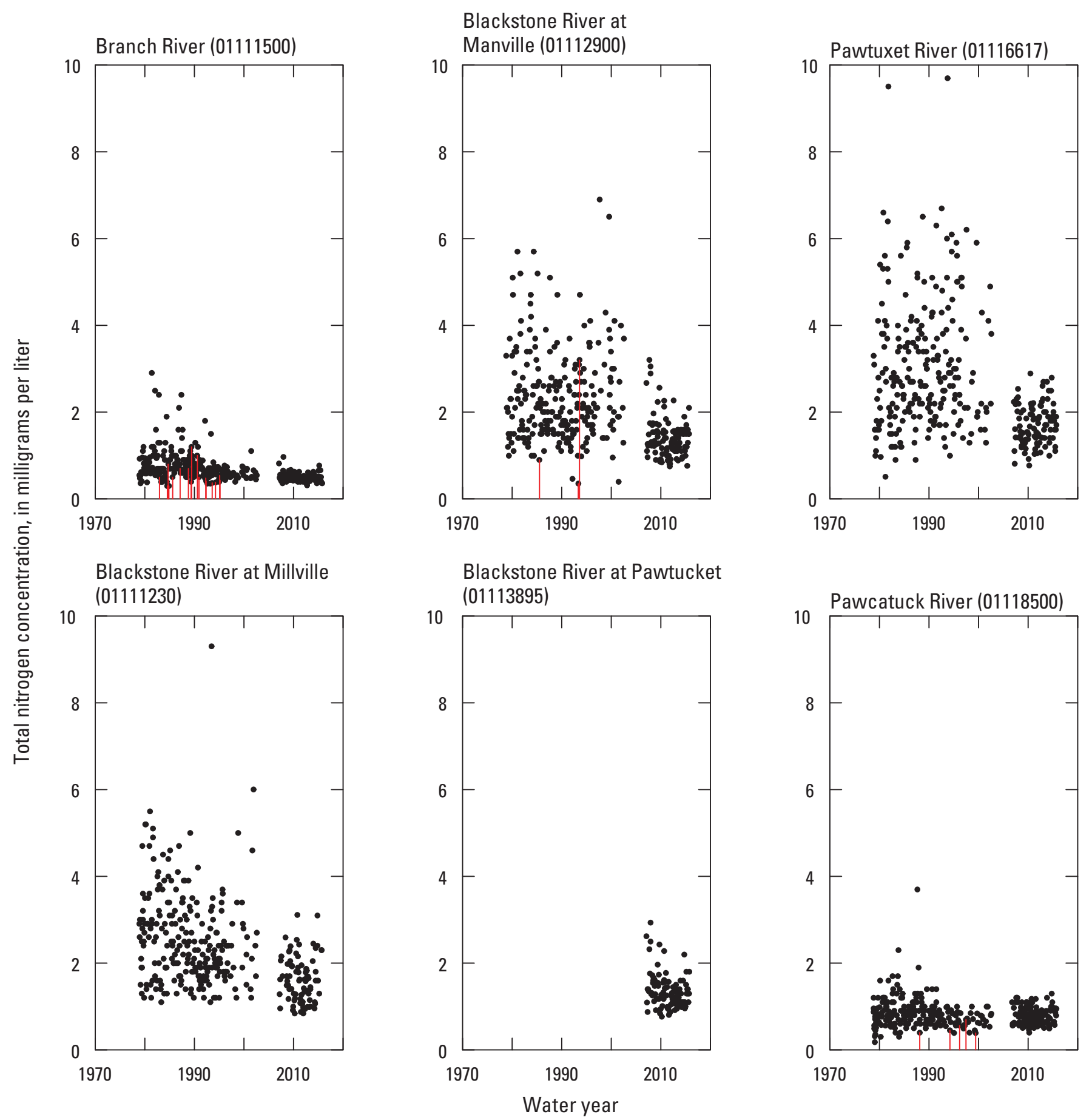

Figure 2. Total nitrogen concentrations in the Branch, Blackstone, Pawtuxet, and Pawcatuck Rivers in Massachusetts and Rhode Island, 1979 through 2015 (2007 through 2015 for Blackstone River at Pawtucket). Vertical red lines indicate values less than the reporting limit. Full station names are listed in table 1. 

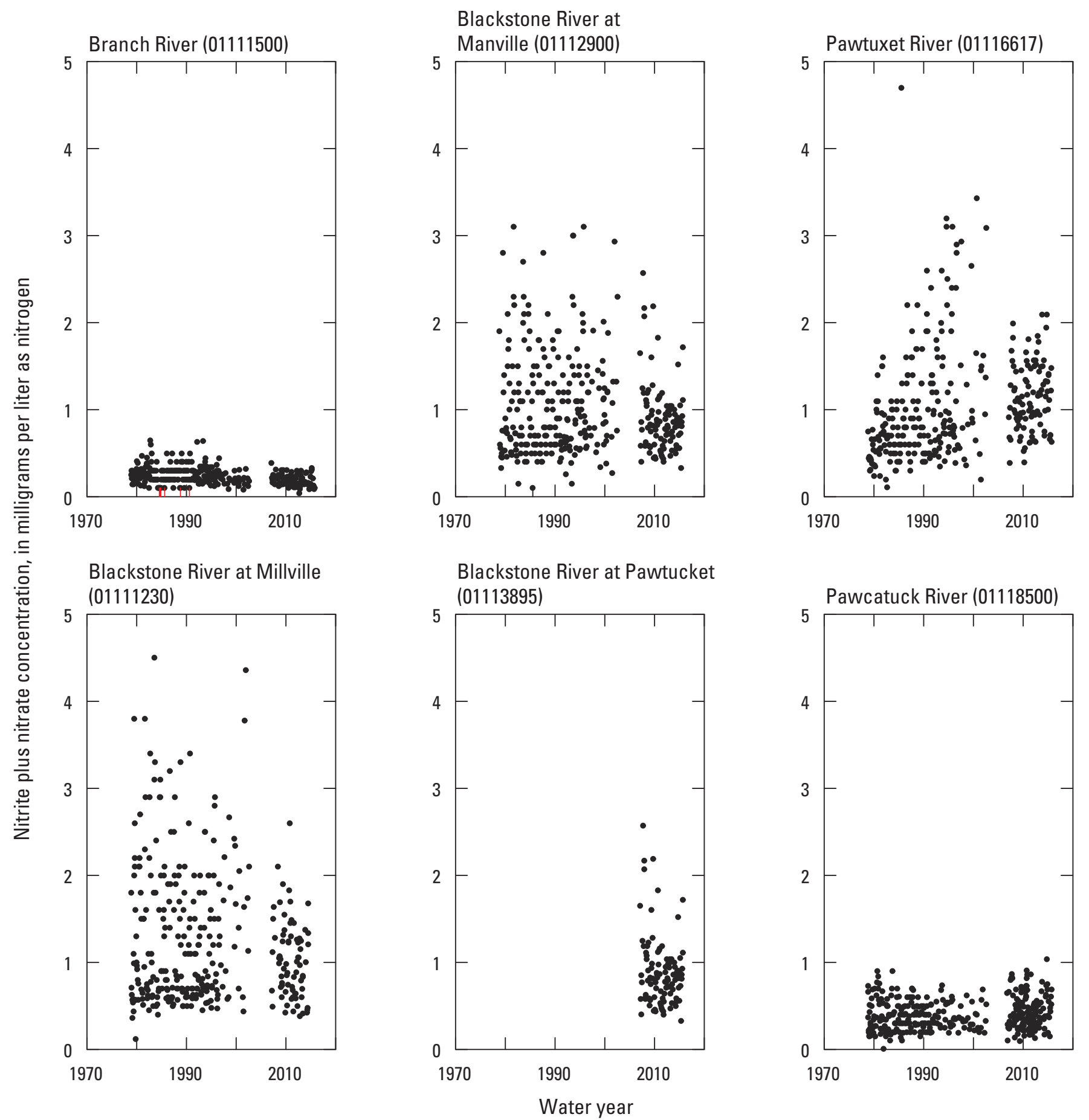

Figure 3. Nitrite plus nitrate concentrations in the Branch, Blackstone, Pawtuxet, and Pawcatuck Rivers in Massachusetts and Rhode Island, 1979 through 2015 (2007 through 2015 for Blackstone River at Pawtucket, and 1979 through 2014 for Blackstone River at Millville). Vertical red lines indicate values less than the reporting limit. Full station names are listed in table 1 . Full station names are listed in table 1. 

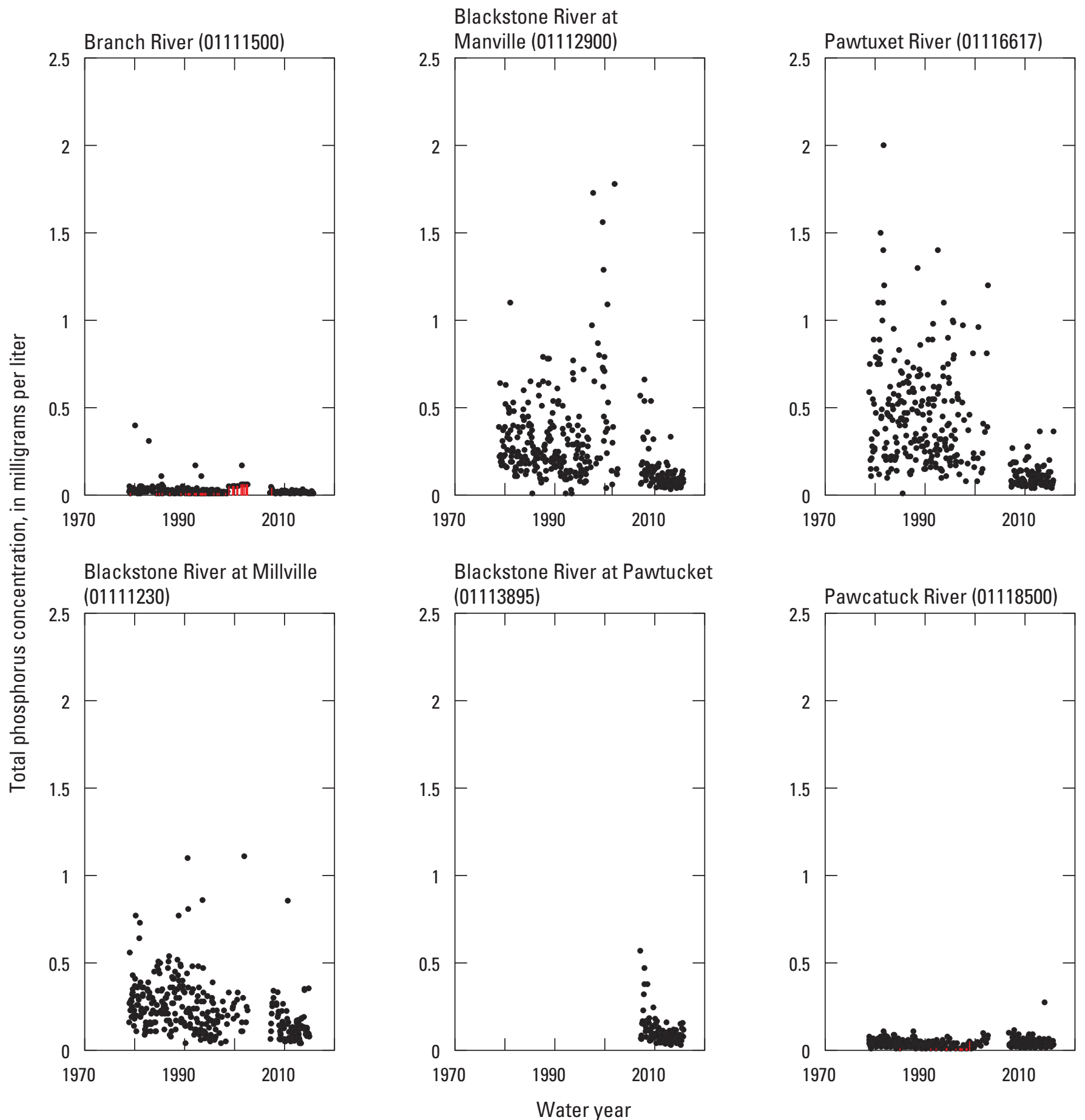

Figure 4. Total phosphorus concentrations in the Branch, Blackstone, Pawtuxet, and Pawcatuck Rivers in Massachusetts and Rhode Island, 1979 through 2015 (2007 through 2015 for Blackstone River at Pawtucket). Vertical red lines indicate values less than the reporting limit. Full station names are listed in table 1. 

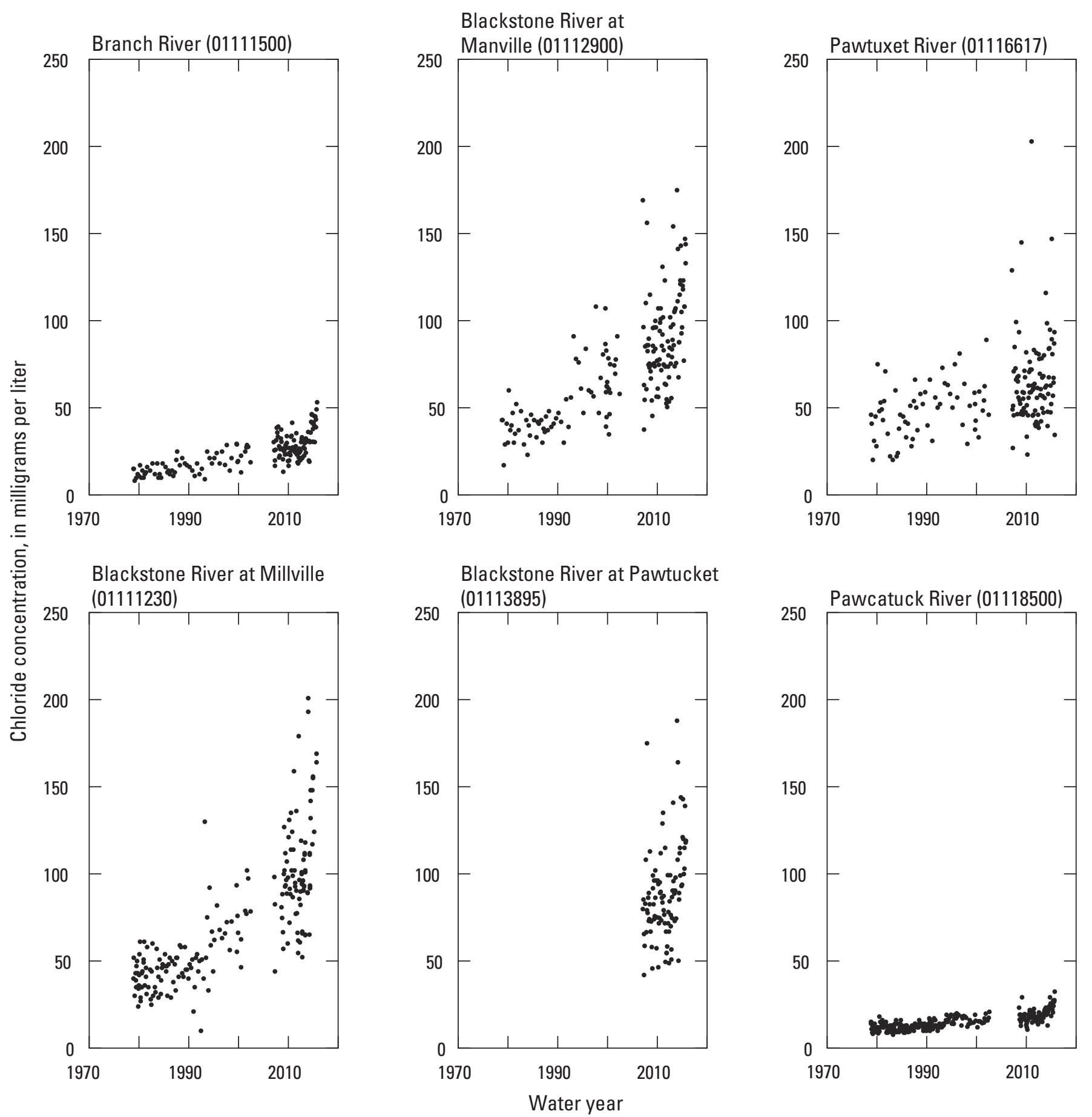

Figure 5. Chloride concentrations in the Branch, Blackstone, Pawtuxet, and Pawcatuck Rivers in Massachusetts and Rhode Island, 1979 through 2015 (2007 through 2015 for Blackstone River at Pawtucket). Full station names are listed in table 1. 

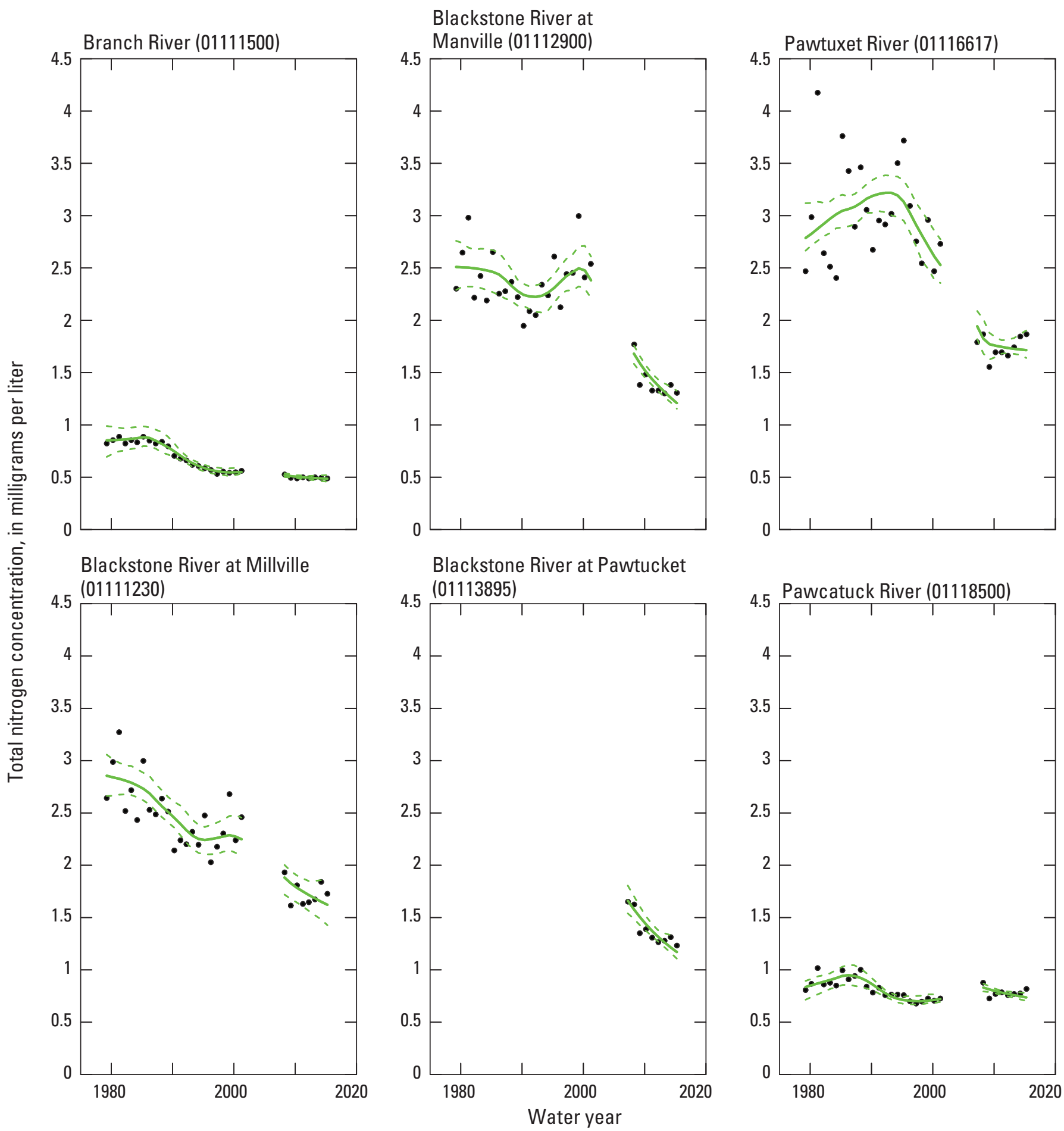

Figure 6. Ninety-percent confidence bands for total nitrogen concentrations in the Branch, Blackstone, Pawtuxet, and Pawcatuck Rivers in Massachusetts and Rhode Island, 1979 through 2015 (2007 through 2015 for Blackstone River at Pawtucket). Black dots are the estimated annual mean concentrations, solid green lines show the annual flow-normalized concentrations, and dashed green lines show the 5th and 95th percentiles of the annual flow-normalized concentrations. Gaps in lines indicate that data were not collected. Full station names are listed in table 1. 

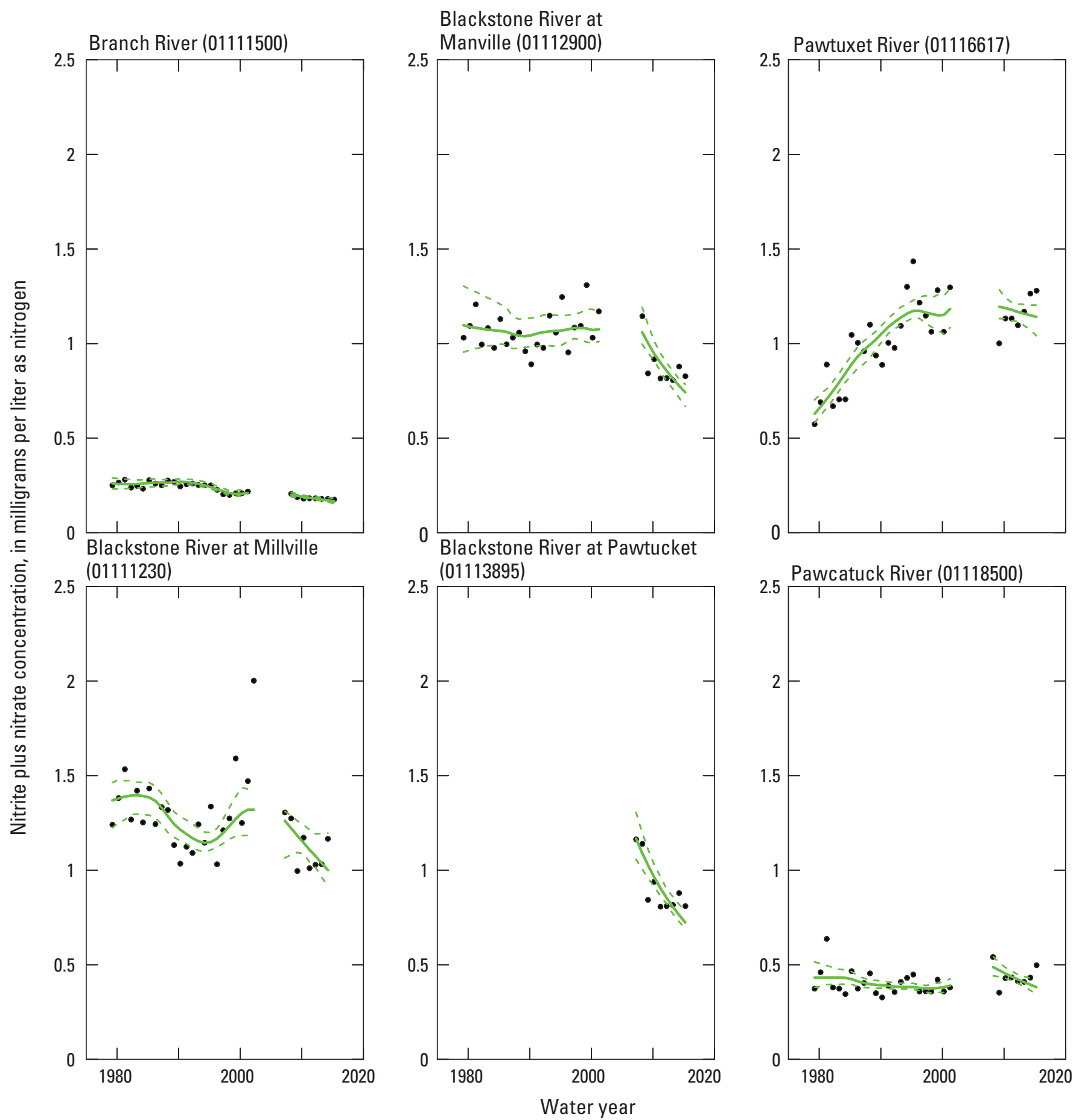

Figure 7. Ninety-percent confidence bands for nitrite plus nitrate concentrations in the Branch, Blackstone, Pawtuxet, and Pawcatuck Rivers in Massachusetts and Rhode Island, 1979 through 2015 (1979 through 2014 for Blackstone at Millville, and 2007 through 2015 for Blackstone River at Pawtucket). Black dots are the estimated annual mean concentrations, solid green lines show the annual flownormalized concentrations, and dashed green lines show the 5th and 95th percentiles of the annual flow-normalized concentrations. Gaps in lines indicate that data were not collected. Full station names are listed in table 1. 

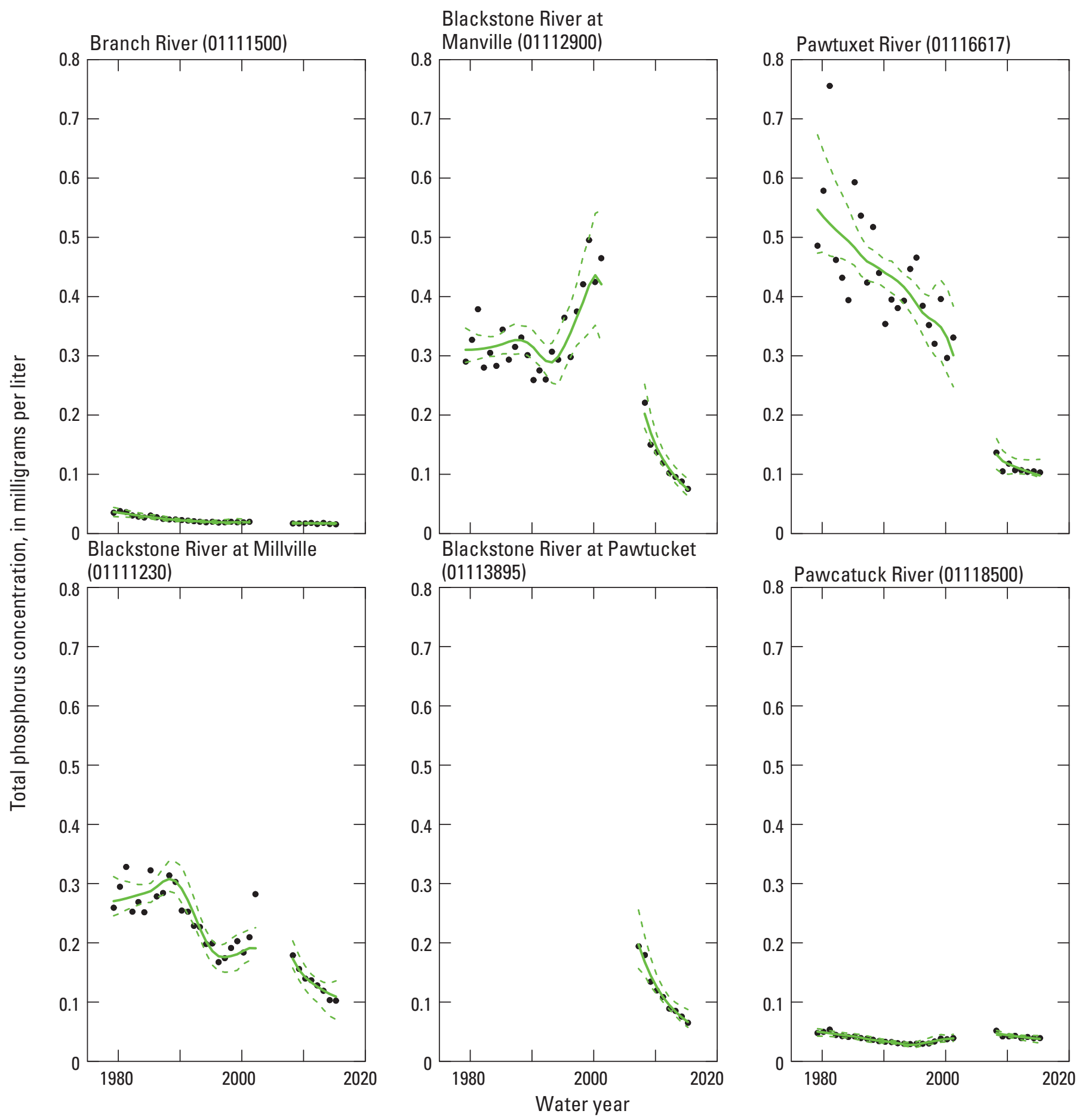

Figure 8. Ninety-percent confidence bands for total phosphorus concentrations in the Branch, Blackstone, Pawtuxet, and Pawcatuck Rivers in Massachusetts and Rhode Island, 1979 through 2015 (2007 through 2015 for Blackstone River at Pawtucket). Black dots are the estimated annual mean concentrations, solid green lines show the annual flow-normalized concentrations, and dashed green lines show the 5th and 95th percentiles of the annual flow-normalized concentrations. Gaps in lines indicate that data were not collected. Full station names are listed in table 1. 

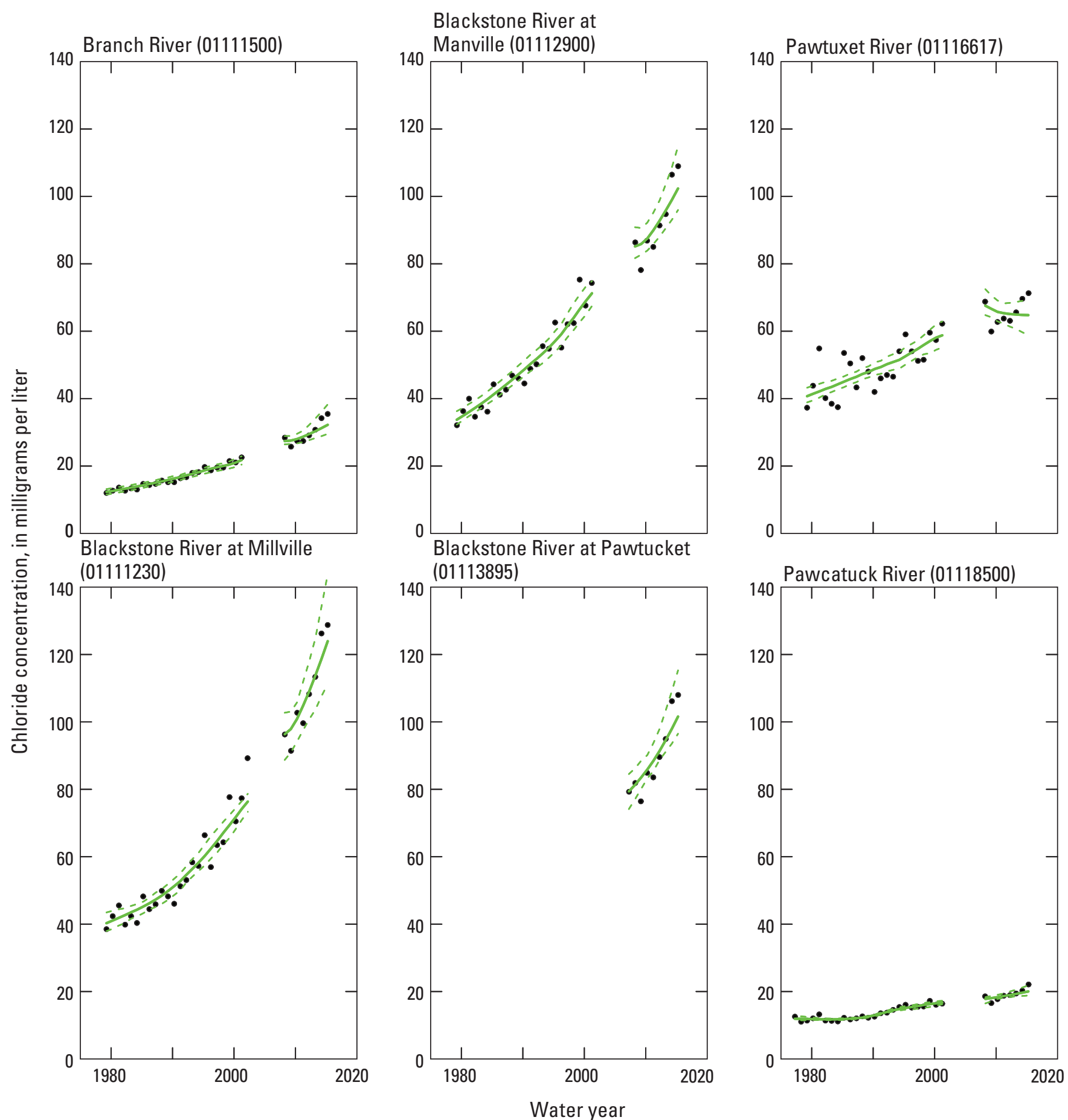

Figure 9. Ninety-percent confidence bands for chloride concentrations in the Branch, Blackstone, Pawtuxet, and Pawcatuck Rivers in Massachusetts and Rhode Island, 1979 through 2015 (2007 through 2015 for Blackstone River at Pawtucket). Black dots are the estimated annual mean concentrations, solid green lines show the annual flow-normalized concentrations, and dashed green lines show the 5th and 95th percentiles of the annual flow-normalized concentrations. Gaps in lines indicate that data were not collected. Full station names are listed in table 1. 

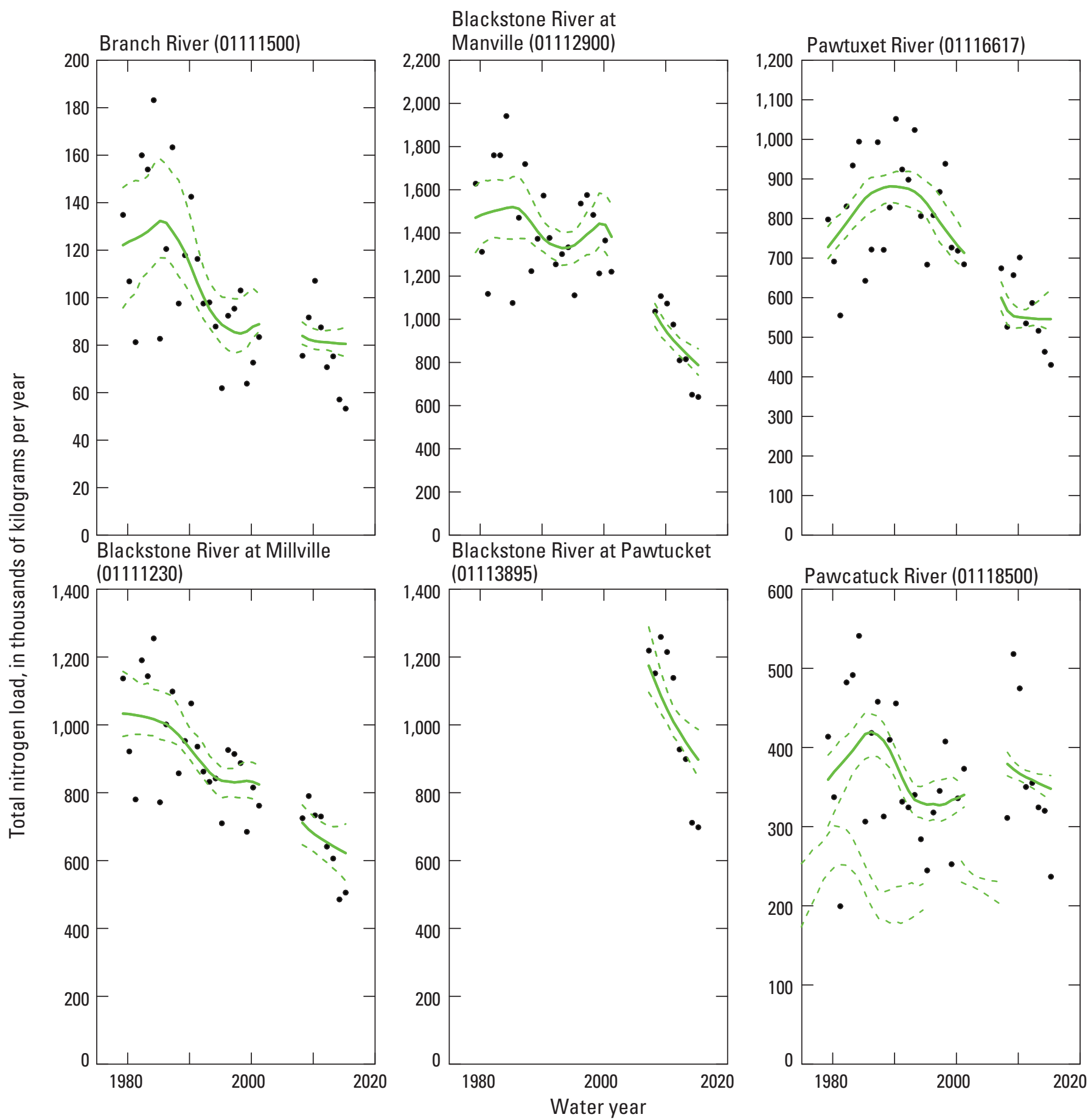

Figure 10. Ninety-percent confidence bands for total nitrogen loads in the Branch, Blackstone, Pawtuxet, and Pawcatuck Rivers in Massachusetts and Rhode Island, 1979 through 2015 (2007 through 2015 for Blackstone River at Pawtucket). Black dots are the estimated annual mean loads, solid green lines show the annual flow-normalized loads, and dashed green lines show the 5th and 95th percentiles of the annual flow-normalized loads. Gaps in lines indicate that data were not collected. Full station names are listed in table 1. 


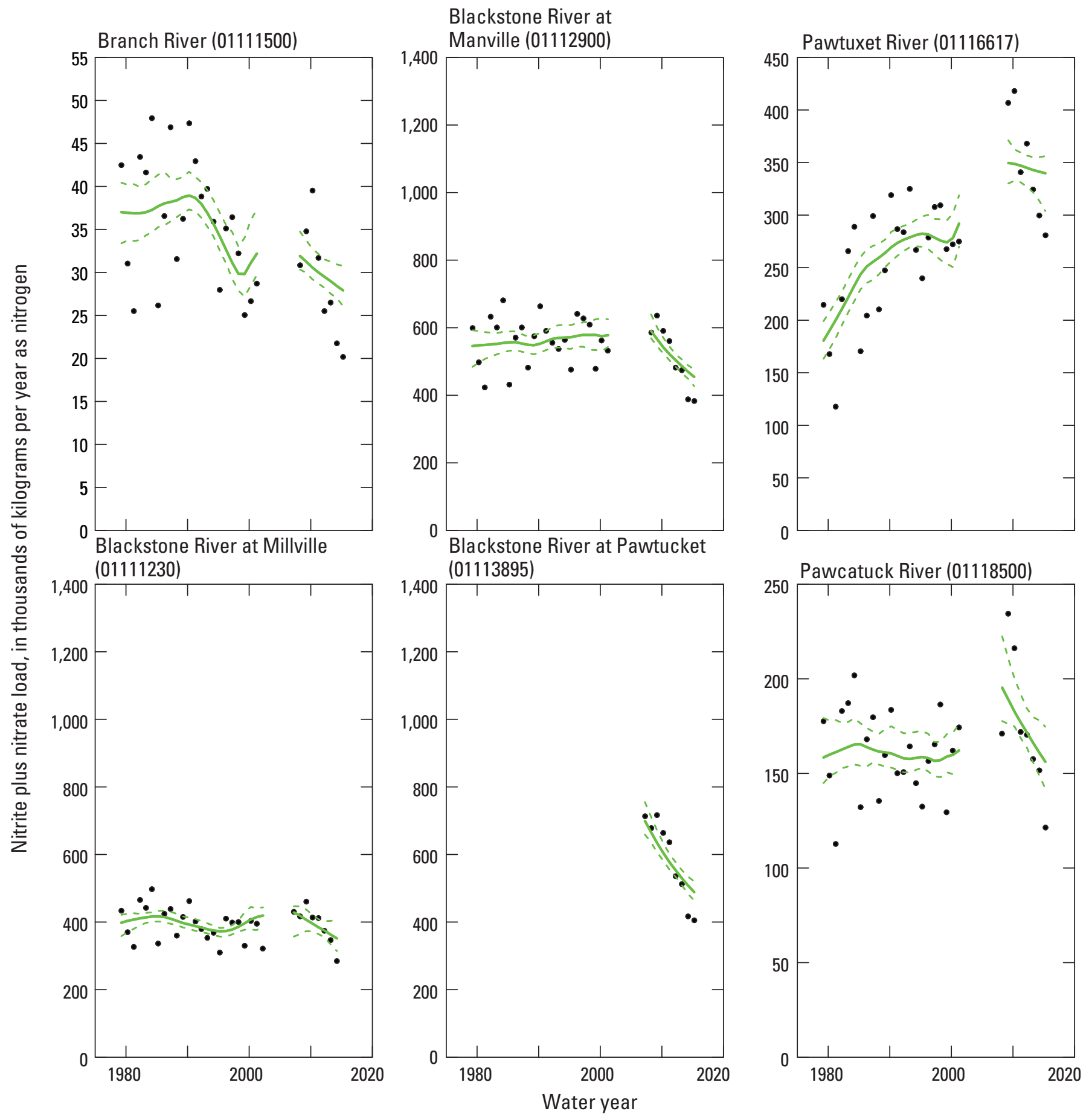

Figure 11. Ninety-percent confidence bands for nitrite plus nitrate loads in the Branch, Blackstone, Pawtuxet, and Pawcatuck Rivers in Massachusetts and Rhode Island, 1979 through 2015 (1979 through 2014 for Blackstone at Millville, and 2007 through 2015 for Blackstone River at Pawtucket). Black dots are the estimated annual mean loads, solid green lines show the annual flow-normalized loads, and dashed green lines show the 5th and 95th percentiles of the annual flow-normalized loads. Gaps in lines indicate that data were not collected. Full station names are listed in table 1. 

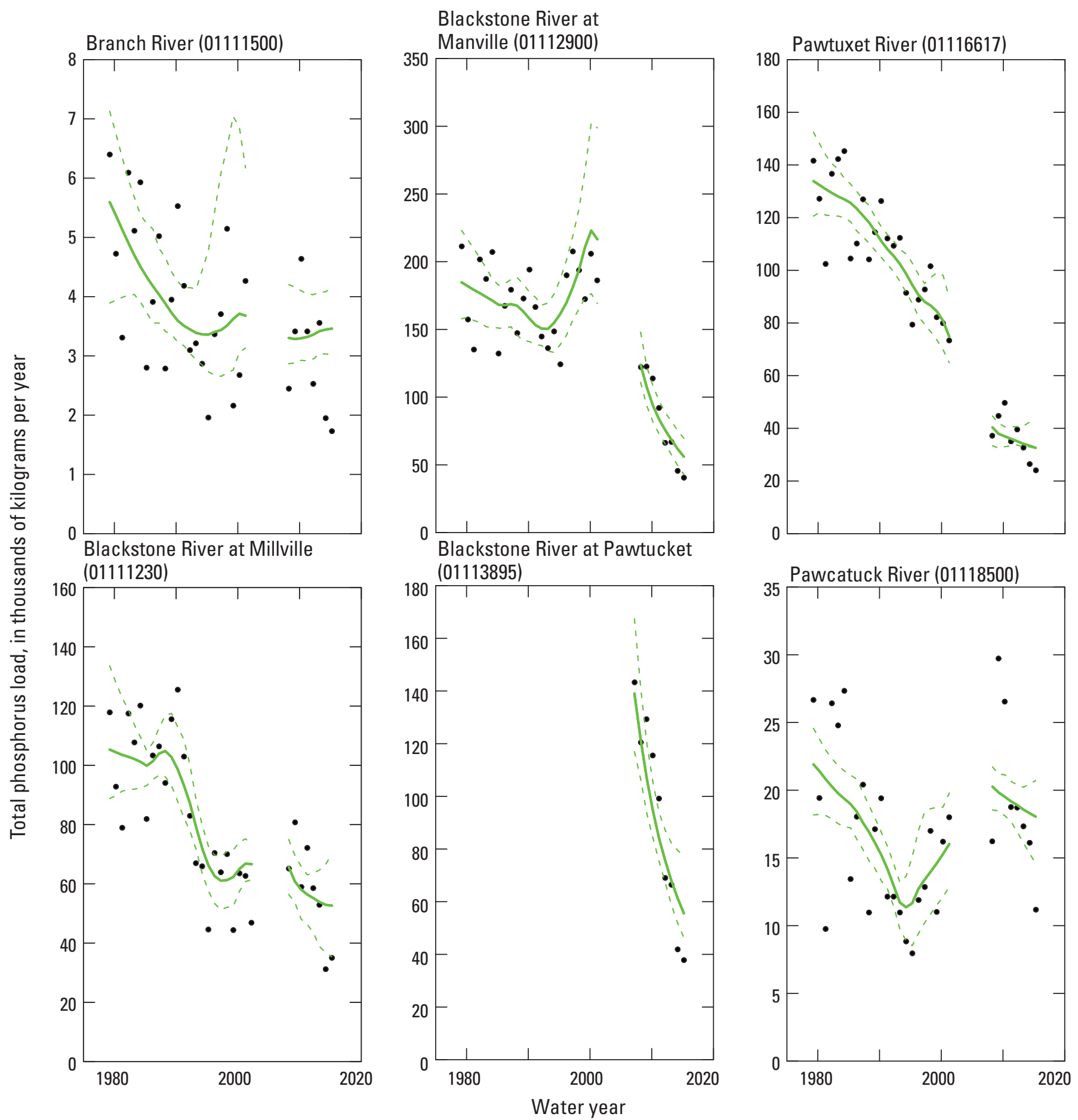

Figure 12. Ninety-percent confidence bands for total phosphorus loads in the Branch, Blackstone, Pawtuxet, and Pawcatuck Rivers in Massachusetts and Rhode Island, 1979 through 2015 (2007 through 2015 for Blackstone River at Pawtucket). Black dots are the estimated annual mean loads, solid green lines show the annual flow-normalized loads, and dashed green lines show the 5th and 95th percentiles of the annual flow-normalized loads. Gaps in lines indicate that data were not collected. Full station names are listed in table 1. 

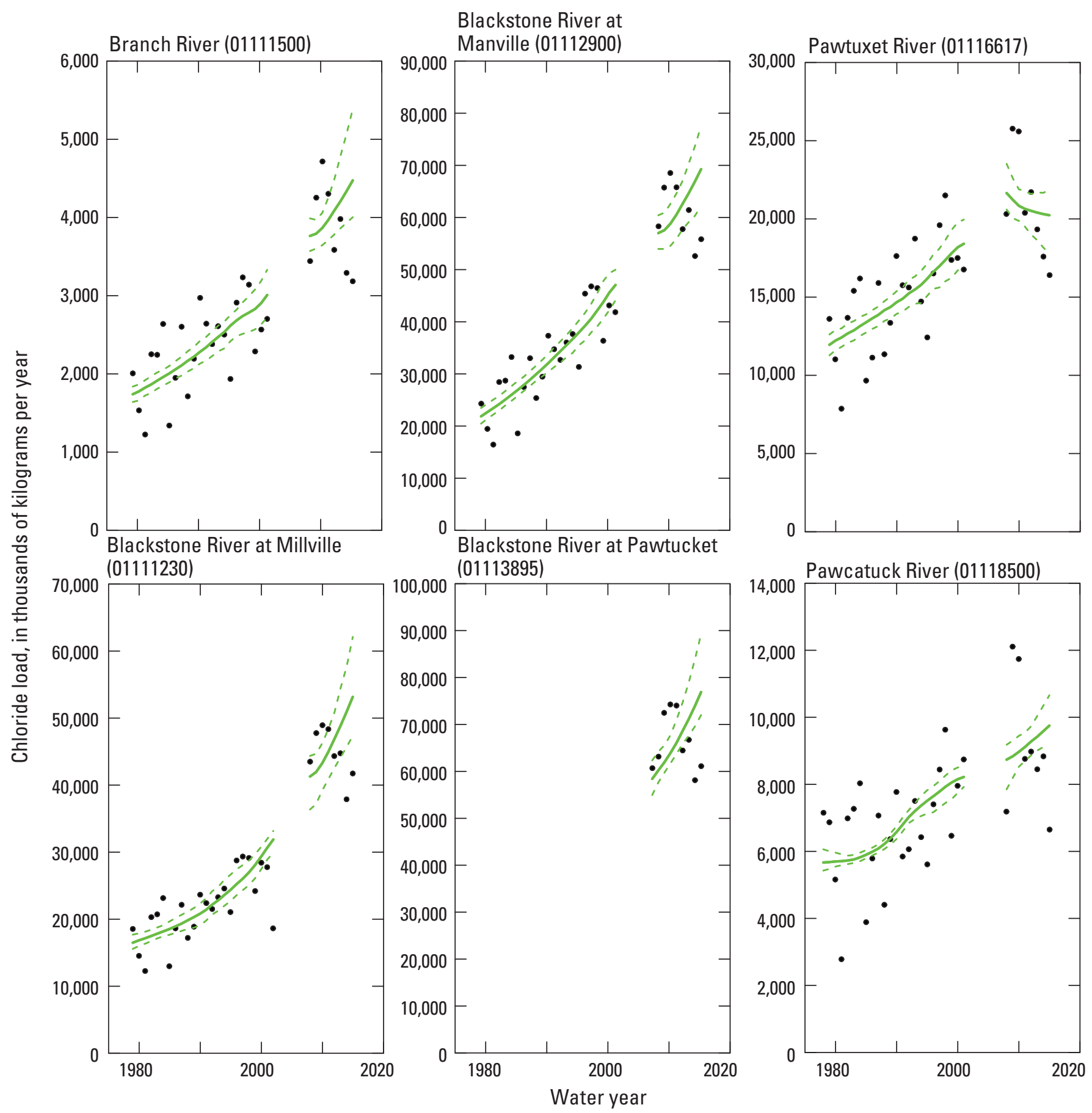

Figure 13. Ninety-percent confidence bands for chloride loads in the Branch, Blackstone, Pawtuxet, and Pawcatuck Rivers in Massachusetts and Rhode Island, 1979 through 2015 (2007 through 2015 for Blackstone River at Pawtucket). Black dots are the estimated annual mean loads, solid green lines show the annual flow-normalized loads, and dashed green lines show the 5th and 95th percentiles of the annual flow-normalized loads. Gaps in lines indicate that data were not collected. Full station names are listed in table 1. 
Table 2. Changes and percent changes in flow-normalized concentrations and loads between water years 1979 and 2015 (2007 and 2015 for streamgage 01113895, and 1979 and 2014 for nitrite plus nitrate for streamgage 01111230) and probabilities of trends in concentration for selected constituents at water-quality-monitoring stations on the Blackstone, Branch, Pawtuxet, and Pawcatuck Rivers in Massachusetts and Rhode Island.

[USGS, U.S. Geological Survey; mg/L, milligram per liter; kg/yr, kilogram per year; MA, Massachusetts; RI, Rhode Island; St., Street]

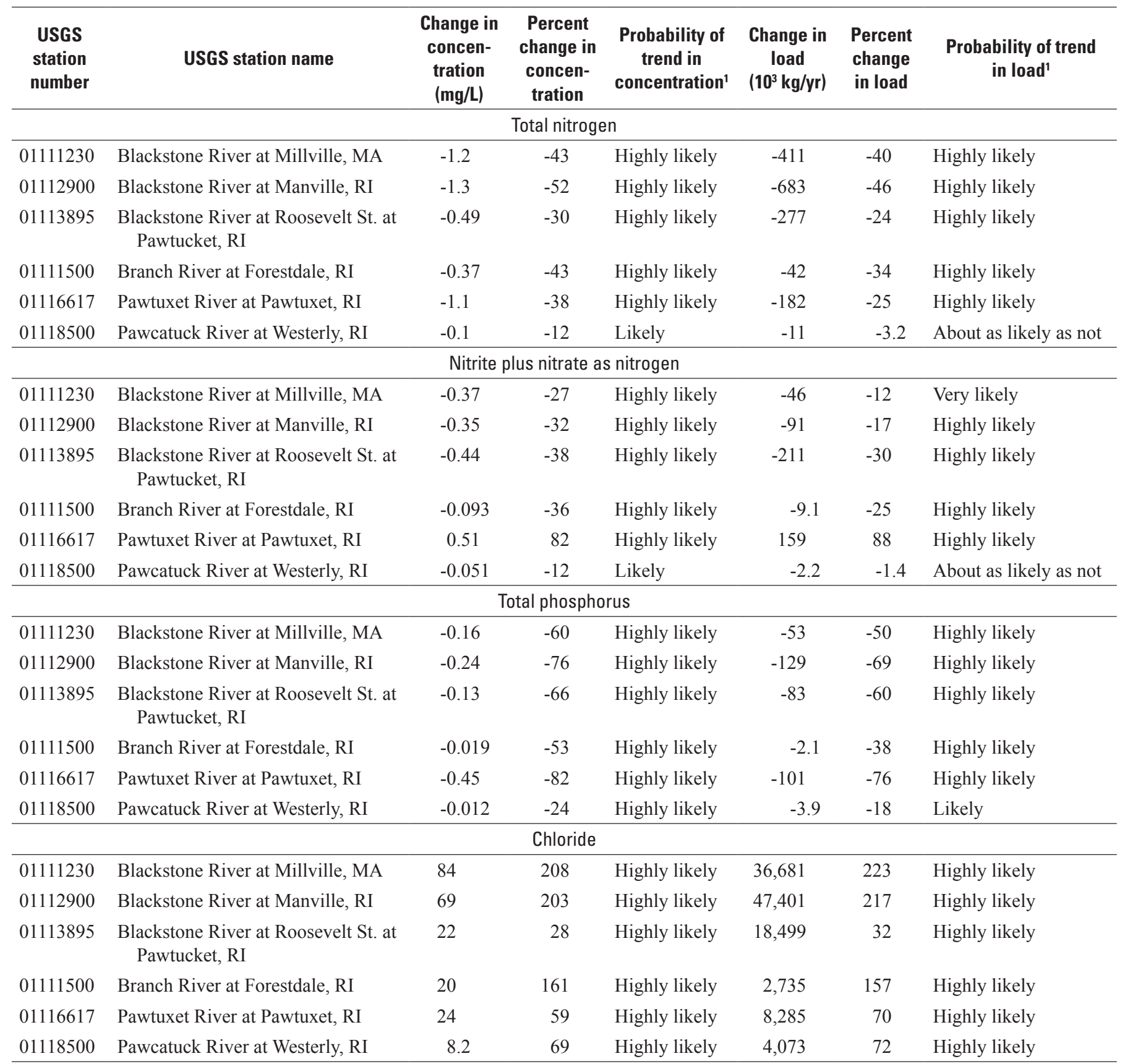

${ }^{1}$ Based on the definitions by range of the posterior mean estimate of the probability of an increasing or decreasing trend, as described in Hirsch and others (2015, table 2). Trend direction is indicated by the sign ( \pm ) shown in this table. 


\section{Changes in Streamflow}

Time-series smoothing methods were used to produce streamflow statistics of the annual median, mean, 7-day minimum, and maximum day streamflow at the streamgages that had long-term streamflow records. Data from 1979 through 2015 were analyzed for the streamgages at the Branch River at Forestdale, R.I. (01111500), the Blackstone River at Woonsocket, R.I. (01112500), the Pawtuxet River at Cranston, R.I. (01116500), and the Pawcatuck River at Westerly, R.I. (01118500) (figs. 14 through 17).

Changes in streamflow statistics were most pronounced for the annual minimum 7-day streamflow, which decreased by 19 to 54 percent between 1979 and 2014; decreases were significant for three of the four rivers (figs. 14-17, table 3). Increases in the maximum daily streamflow between 1979 and 2015 were substantial at the Blackstone River at Woonsocket (24 percent) and the Pawtuxet River at Cranston (34 percent). However, there is a characteristic common to the maximum day flows at all of the sites in that the highest flows are almost entirely in the first 10 years and last 10 years of this period. This is more suggestive of a quasi-periodic climate oscillation than a long-term secular trend. Annual mean daily flows increased 1.2 to 11 percent during the study period at all streamgages except for the Branch River streamgage, where flows decreased 7.5 percent. Annual median daily flows decreased 4.5 and 8.5 percent at the Blackstone and
Branch River streamgages, respectively, whereas they increased 6.8 and 11 percent at the Pawtuxet and Pawcatuck streamgages, respectively.

The analysis of streamflow trends from the output of the flow history analysis showed visible increases in the annual maximum day flows and mixed, small increases and decreases in the annual mean daily and median daily flows (table 3 ). These reported trends were not significant at $p \leq 0.10$ when subjected to the Mann-Kendall test.

The streamflow statistics for the annual 7-day minimum appeared to decrease at all four sites; however, the decreases were not significant at $p<0.1$ for the streamflow record at the Pawtuxet River. Decreases in annual 7-day minimum flows are often associated with land use areas with increased impervious surface coverage, such as paved roads and parking lots, that can decrease minimum streamflows through the loss of groundwater recharge (Arnold and Gibbons, 2007). Between 1990 and 2000, increases in urbanization in the Northeast have been the largest in the country, with urbanization increasing 5.7 percent in Rhode Island and 5.0 percent in Massachusetts (Nowak and Walton, 2005). Changes to the annual 7-day minimum may be related to upstream water withdrawals, increased pumping stress on the groundwater system, or changes in climate and precipitation. The interactions between climate, landuse changes, and water withdrawals/diversions are beyond the scope of this study; however, the findings on streamflows have implications for the dilution of nutrients and other pollutants during low flows.

Table 3. Percent changes in statistics between 1979 and 2015 at stations on the Branch, Blackstone, Pawtuxet, and Pawcatuck Rivers in Rhode Island.

[Shading indicates trend significant at the 90-percent confidence interval. USGS, U.S. Geological Survey; RI, Rhode Island]

\begin{tabular}{clcccc}
\hline \multirow{2}{*}{ USGS station number } & \multirow{2}{*}{ USGS station name } & \multicolumn{3}{c}{ Percent change between water years 1979 and 2015 } \\
\cline { 3 - 6 } & & Maximum day & Mean daily & Median daily & 7-day minimum \\
\hline 01111500 & Branch River at Forestdale, RI & 1.6 & -7.5 & -8.5 & -54 \\
01112500 & Blackstone River at Woonsocket, RI & 24 & 1.2 & -4.5 & -35 \\
01116500 & Pawtuxet River at Cranston, RI & 34 & 11 & 6.8 & -19 \\
01118500 & Pawcatuck River at Westerly, RI & 9.6 & 6.5 & -34 \\
\hline
\end{tabular}




\section{Branch River at Forestdale, Rhode Island (01111500)}
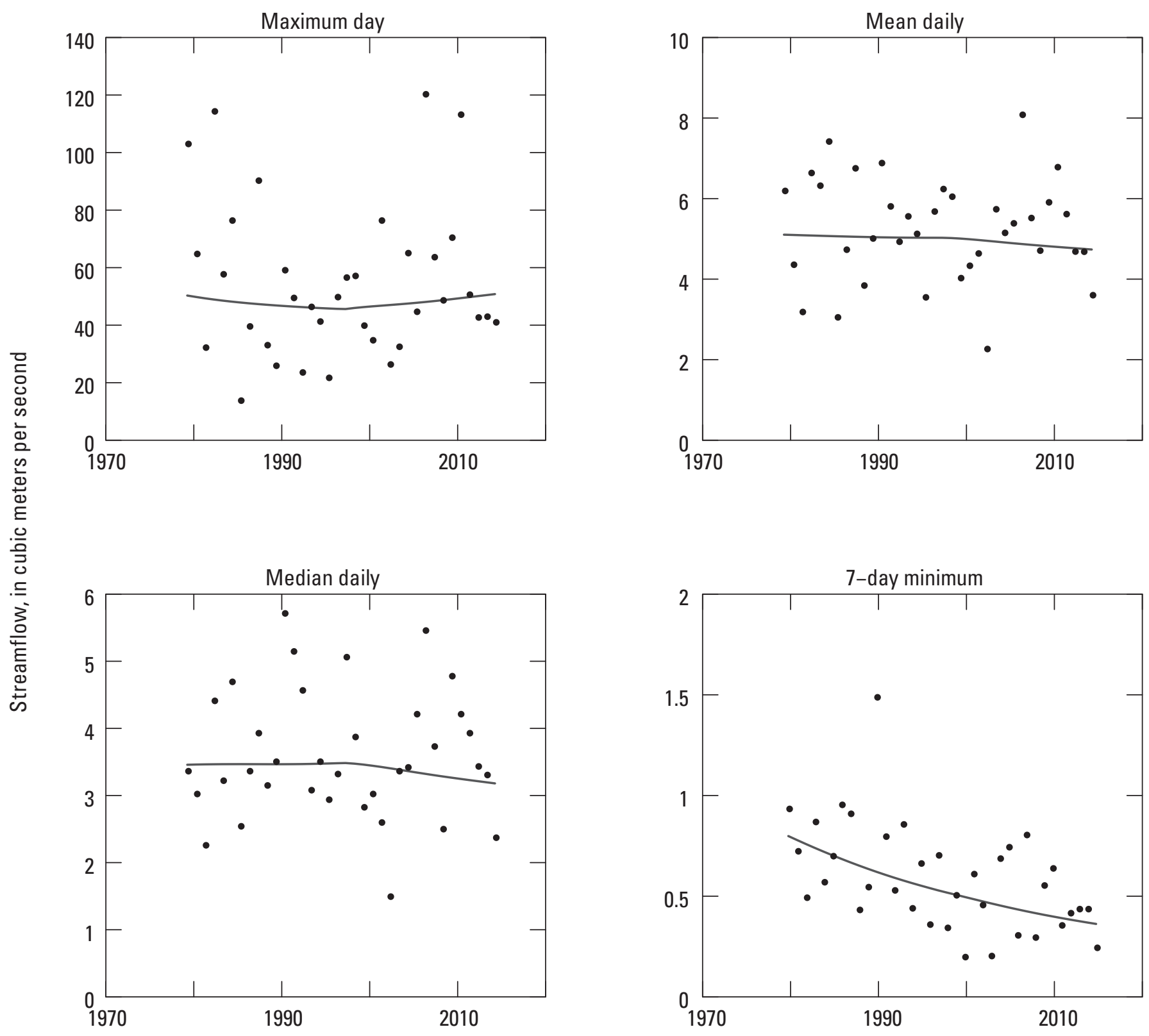

Water year

Figure 14. Annual streamflow statistics (dots) of maximum day, mean daily, median daily, and 7-day minimum streamflow, and locally weighted scatterplot smooth (solid line) at the Branch River at Forestdale, Rhode Island (streamgage 01111500 ), 1979 through 2015. 
Blackstone River at Woonsocket, Rhode Island (01112500)
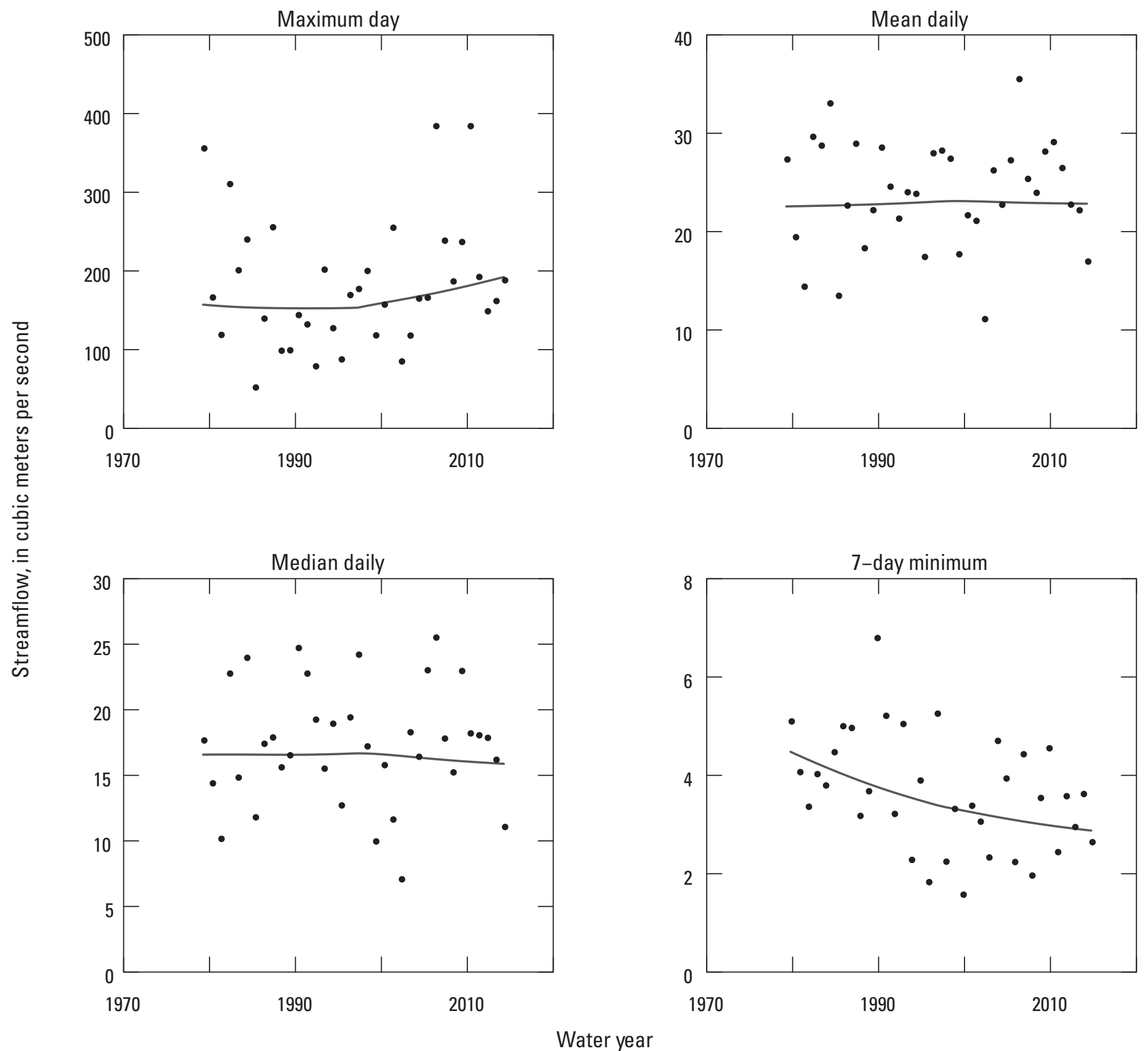

Figure 15. Annual streamflow statistics (dots) of maximum day, mean daily, median daily, and 7-day minimum streamflow, and locally weighted scatterplot smooth (solid line) at the Blackstone River at Woonsocket, Rhode Island (streamgage 01112500), 1979 through 2015. 


\section{Pawtuxet River at Cranston, Rhode Island (01116500)}
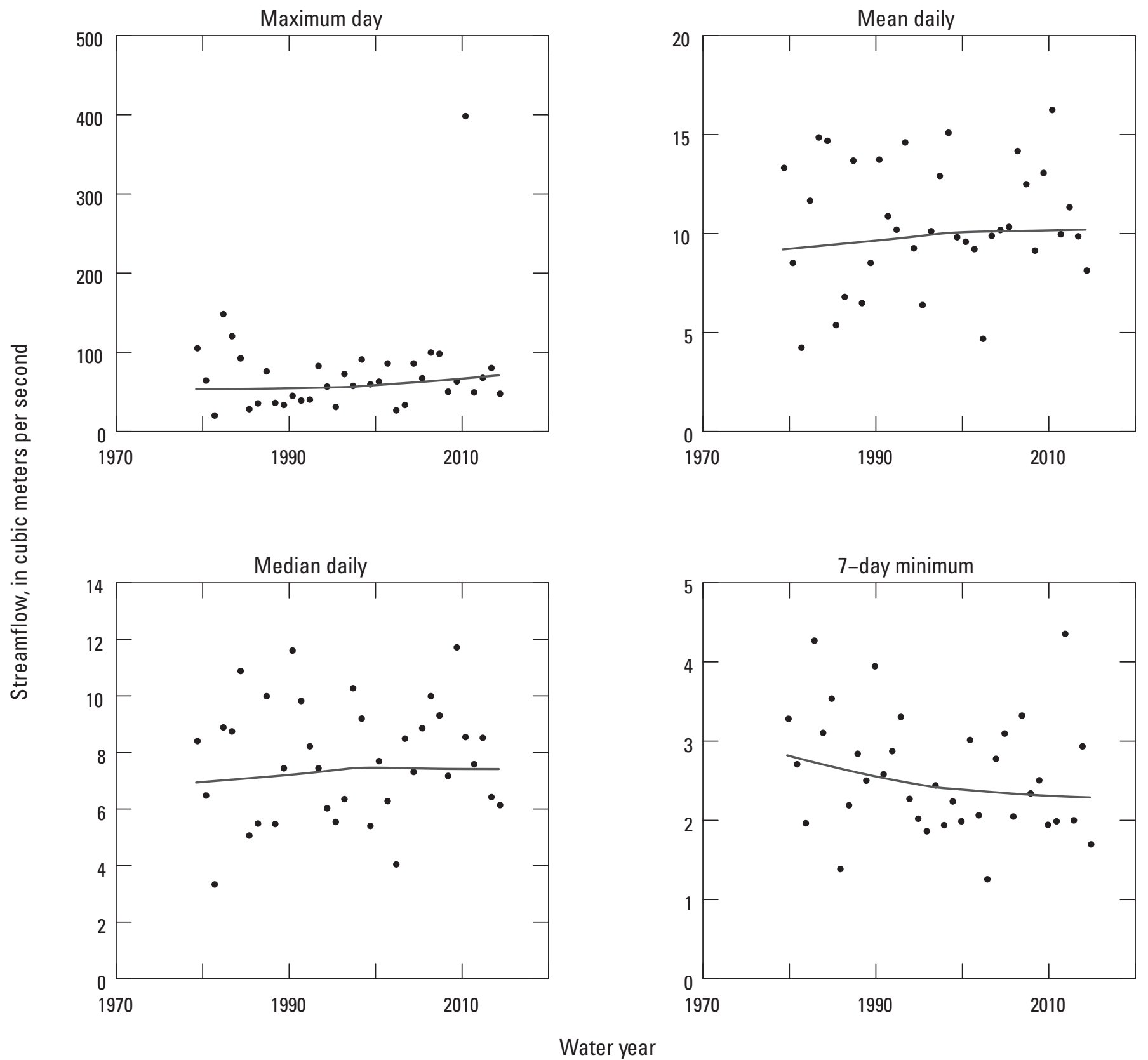

Figure 16. Annual streamflow statistics (dots) of the maximum day, mean daily, median daily, and 7-day minimum streamflow, and locally weighted scatterplot smooth (solid line) for the Pawtuxet River at Cranston, Rhode Island (streamgage 01116500), 1979 through 2015. 
Pawcatuck River at Westerly, Rhode Island (01118500)
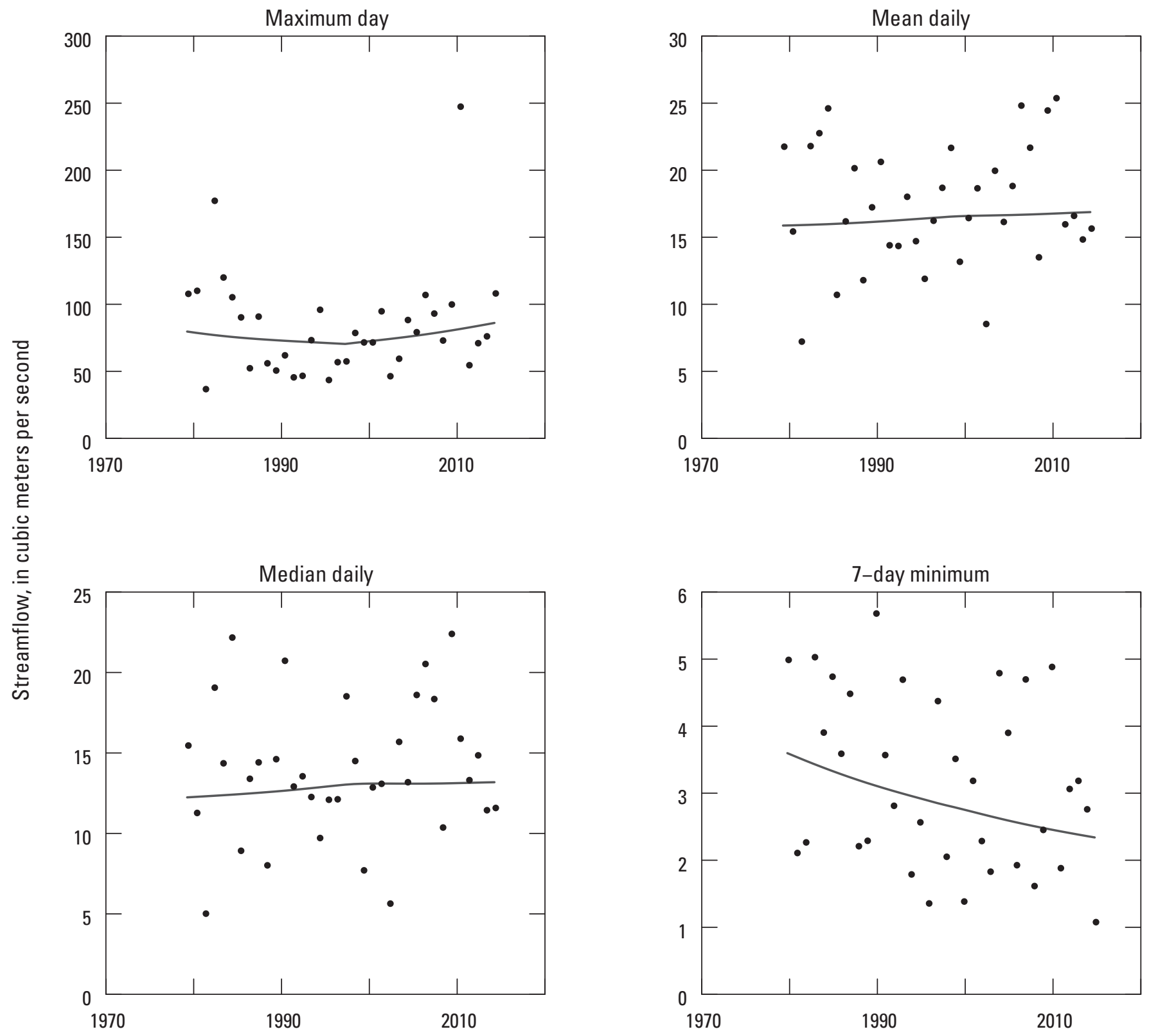

Water year

Figure 17. Annual streamflow statistics (dots) of the maximum day, mean daily, median daily, and 7-day minimum streamflow, and locally weighted scatterplot smooth (solid line) for the Pawcatuck River at Westerly, Rhode Island (streamgage 01118500), 1979 through 2015. 


\section{Summary}

This study, by the U.S. Geological Survey in cooperation with the Rhode Island Department of Environmental Management, the Rhode Island Water Resources Board, and the U.S. Environmental Protection Agency, documents longterm changes of streamflow, total nitrogen, nitrite plus nitrate $\left(\mathrm{NO}_{2}+\mathrm{NO}_{3}\right)$, total phosphorus, and chloride at six locations on four Massachusetts and Rhode Island streams that flow to Narragansett Bay and Little Narragansett Bay. The method used, Weighted Regressions on Time, Discharge, and Season, calculates trends in concentrations and loads by removing the effects of year-to-year variation in streamflow. Trend analyses of concentrations and loads were conducted at six water-quality-monitoring stations, and flow history analyses were conducted at four long-term streamgages for water years 1979-2015.

Results from this study indicate that the flow-normalized total nitrogen, $\mathrm{NO}_{2}+\mathrm{NO}_{3}$, and total phosphorus concentrations and loads from the rivers generally decreased since 1979, except in the Pawtuxet River, where $\mathrm{NO}_{2}+\mathrm{NO}_{3}$ concentrations and loads increased. Flow-adjusted loads decreased in the Blackstone River up to 46 percent for total nitrogen, 17 percent for $\mathrm{NO}_{2}+\mathrm{NO}_{3}$, and 69 percent for total phosphorus. Decreases were also observed in the other rivers, except for the Pawtuxet River, where flow-normalized $\mathrm{NO}_{2}+\mathrm{NO}_{3}$ concentrations and loads increased, by 82 and 88 percent, respectively. Increases in chloride concentrations and loads were observed in all rivers. The largest increases (more than 200 percent) in flow-normalized chloride concentrations and loads were observed in the Blackstone River at both Millville and Manville. This represented an increase in flow-normalized concentrations of 84 and 69 milligrams per liter, respectively.

Analysis of changes in river flow at four long-term streamgages showed small, increasing trends in annual mean daily streamflow in 3 of the 4 rivers, but the trends were not significant. All rivers had decreases in streamflow for the annual 7-day minimum, but only the Blackstone, Branch, and Pawcatuck Rivers had decreasing trends that were significant. The Blackstone and Pawtuxet Rivers, located in more industrialized areas, had the largest increases in the annual maximum daily flows and had significant decreases in the annual 7-day minimum flows. The Branch River, located in a less developed watershed, had decreases in annual values of the mean and median daily streamflow and significant decreases in the annual 7-day minimum.

\section{References Cited}

Arnold, C.L., and Gibbons, D.J., 2007, Impervious surface coverage - The emergence of a key environmental indicator: Journal of the American Planning Association, v. 62, no. p 243-258. [Also available at http://dx.doi.org/10.1080/01944369608975688.]
Barbaro, J.R., and Zarriello, P.J., 2007, A precipitation-runoff model for the Blackstone River Basin, Massachusetts and Rhode Island: U.S. Geological Survey Scientific Investigations Report 2006-5213, 95 p., accessed September 30, 2016, at http://pubs.usgs.gov/sir/2006/5213/.

Blackstone River Valley National Heritage Corridor Commission, 1998, Natural resources inventory and assessment: John H. Chafee Blackstone River Valley National Heritage Corridor Commission, 16 p., accessed April 12, 2016, at https://www.nps.gov/blac/learn/nature/upload/NRInv.pdf.

Breault, R.F., Zarriello, P.J., Bent, G.C., Masterson, J.P., Granato, G.E., Scherer, J.E., and Crawley, K.M., 2009, Effects of water-management strategies on water resources in the Pawcatuck River Basin, southwestern Rhode Island and southeastern Connecticut: U.S. Geological Survey Circular 1340, 16 p., accessed March 21, 2016, at http://pubs.usgs.gov/circ/circ1340.

Corsi, S.R., De Cicco, L.A., Lutz, M.A., and Hirsch, R.M., 2015, River chloride trends in snow-affected urban watersheds-Increasing concentrations outpace urban growth rate and are common among all seasons: Science of the Total Environment, v. 508, p. 488-497, accessed October 6, 2016, at http://www.sciencedirect.com/science/article/pii/ S0048969714017148.

Desbonnet, Alan, and Costa-Pierce, B.A., eds, 2008, Science for ecosystem-based management-Narragansett Bay in the 21st century: New York, Springer, 570 p.

Fishman, M.J., and Friedman, L.C., eds., 1989, Methods for determination of inorganic substances in water and fluvial sediments: U.S. Geological Survey Techniques of Water-Resources Investigations, book 5, chap. A1, 545 p., accessed March 11, 2016, at https://pubs.usgs.gov/twri/ twri5-a1/.

Fulweiler, R.W., and Nixon, S.W., 2005, Export of nitrogen, phosphorus, and suspended solids from a southern New England watershed to Little Narragansett Bay: Biogeochemistry, v. 76, p. 567-593.

Goolsby, D.A., and Battaglin, W.A., 2001, Long-term changes in concentrations and flux of nitrogen in the Mississippi River Basin, USA: Hydrological Processes, v. 15, no. 7, p. 1209-1226, accessed March 11, 2016, at http://dx.doi.org/10.1002/hyp.210.

Helsel, D.R., and Hirsch, R.M., 2002, Statistical methods in water resources: U.S. Geological Survey Techniques of Water-Resource Investigations, book 4, chap. A3, 523 p. [Also available at http://pubs.usgs.gov/twri/twri4a3/.] 
Hirsch, R.M., 2014, Large biases in regression-based constituent flux estimates - Causes and diagnostic tools: Journal of the American Water Resources Association, v. 50, no. 6, p. 1401-1424, accessed April 25, 2016, at https://pubs.er.usgs.gov/publication/70108400.

Hirsch, R.M., Archfield, S.A., and De Cicco, L.A., 2015, A bootstrap method for estimating uncertainty of water quality trends: Environmental Modelling and Software, v. 73, p. 148-166, accessed September 23, 2016, at http://dx.doi.org/10.1016/j.envsoft.2015.07.017.

Hirsch, R.M., and De Cicco, Laura, 2015, User guide to Exploration and Graphics for RivEr Trends (EGRET) and dataRetrieval — R packages for hydrologic data: U.S. Geological Survey Techniques and Methods, book 4, chap. A10, 94 p., accessed April 12, 2016, at http://dx.doi.org/10.3133/ tm4A10.

Hirsch, R.M., and De Cicco, L.A., 2016, Introduction to EGRET confidence intervals: R statistical package vignette, accessed July 6, 2016, at https://github.com/USGS-R/ EGRETci/blob/master/vignettes/EGRETci.Rmd.

Hirsch, R.M., Moyer, D.L., and Archfield, S.A., 2010, Weighted Regressions on Time, Discharge, and Season (WRTDS), with an application to Chesapeake Bay River inputs: Journal of the American Water Resources Association, v. 46, no. 5, p. 857-880, accessed April 25, 2016, at http://dx.doi.org/10.1111/j.1752-1688.2010.00482.x.

Klyberg, Albert, 2012, Mr. Blackstone's river, Narragansett Bay Journal 22-2-12: Narragansett Bay Estuary Program, spring 2012, 4 p., accessed June 8, 2016, at http://www.nbep.org/journals/22-2-12/MrBlackstone.pdf.

Mullaney, J.R., 2016, Nutrient, organic carbon, and chloride concentrations and loads in selected Long Island Sound tributaries-Four decades of change following the passage of the federal clean water act: U.S. Geological Survey Scientific Investigations Report 2015-5189, 47 p., accessed April 12, 2016, at http://dx.doi.org/10.3133/sir20155189.

Nowak, D.J., and Walton, J.T., 2005, Projected urban growth (2000-2050) and its estimated impact on the US forest resource: Journal of Forestry, December, p. 383-389, accessed September 29, 2016, at http://www.nrs.fs.fed.us/ pubs/7959/.
Patton, C.J., and Kryskalla, J.R., 2003, Methods of analysis by the U.S. Geological Survey National Water Quality Laboratory-Evaluation of alkaline persulfate digestion as an alternative to Kjeldahl digestion for determination of total and dissolved nitrogen and phosphorus in water: U.S. Geological Survey Water-Resources Investigations Report 03-4174, $33 \mathrm{p}$.

Patton, C.J., and Kryskalla, J.R., 2011, Colorimetric determination of nitrate plus nitrite in water by enzymatic reduction, automated discrete analyzer methods: U.S. Geological Survey Techniques and Methods, book 5, chap. B8, 34 p., accessed April 12, 2016, at http://pubs.usgs.gov/tm/05b08/.

Patton, C.J., and Truitt, E.P., 2000, Methods of analysis by the U.S. Geological Survey National Water Quality Laboratory-Determination of ammonium plus organic nitrogen by a Kjeldahl digestion method and an automated photometric finish that includes digest cleanup by gas diffusion: U.S. Geological Survey Open-File Report 00-170, 31 p., accessed April 12, 2016, at http://pubs.usgs.gov/ of/2000/0170/report.pdf.

Rhode Island Department of Environmental Management, 2013, Total maximum daily load for Blackstone River watershed-Pathogen and trace metals impairments: Rhode Island Department of Environmental Management, Office of Water Resources, final report, February 2013, 176 p., accessed September 30, 2016, at http://www.dem.ri.gov/ programs/benviron/water/quality/rest/pdfs/blackstn.pdf.

Rhode Island Department of Environmental Management, 2016, Introduction to Narragansett Bay: Rhode Island Department of Environmental Management Web page, accessed September 21, 2016, at http://www.dem.ri.gov/ programs/emergencyresponse/bart/nbay.php.

Rus, D.L., Patton, C.J., Mueller, D.K., and Crawford, C.G., 2012, Assessing total nitrogen in surface-water samplesPrecision and bias of analytical and computational methods: U.S. Geological Survey Scientific Investigations Report 2012-5281, 38 p.

Stenback, G.A., Crumpton, W.G., Schilling, K.E., and Helmers, M.J., 2011, Rating curve estimation of nutrient loads in Iowa rivers: Journal of Hydrology, v. 396, p. 158-169.

U.S. Census Bureau, 2015, Rhode Island population estimates July 1, 2015 (V2015): U.S. Census Bureau Quick Facts database, accessed April 25, 2016, at http://www.census.gov/quickfacts/table/PST045215/44/. 
U.S. Geological Survey, 2013, Guidance on methods for determining the concentration of total nitrogen in whole-water samples: U.S. Geological Survey Office of Water Quality Technical Memorandum 2013.01, accessed April 26, 2016, at https://water.usgs.gov/admin/memo/QW/qw2013.01.pdf.

U.S. Geological Survey, 2016, USGS water data for the nation: U.S. Geological Survey National Water Information System Web Interface, accessed September 2016 at http://dx.doi.org/10.5066/F7P55KJN.

Zimmerman, C.F., Keefe, C.W., and Bashe, Jerry, 1997, Method 440.0-Determination of carbon and nitrogen in sediments and particulates of estuarine/coastal waters using elemental analysis: U.S. Environmental Protection Agency EPA/600/R-15/009, 10 p. [Also available at https://cfpub.epa.gov/si/si_public_record_report. cfm?dirEntryId=309418.] 

Appendixes 



\section{Appendix 1. Tables of Data Sources, Laboratory Methods, and Flux-Bias Statistics}

Table 1-1. Sources of measured, estimated, and simulated data at stations on the Blackstone, Branch, Pawtuxet, and Pawcatuck Rivers in Massachusetts and Rhode Island, water years 1979-2015.

Table 1-2. Summary of water-quality laboratory method references for samples collected at water-quality-monitoring stations on the Blackstone, Branch, Pawtuxet, and Pawcatuck Rivers in Massachusetts and Rhode Island, water years 1979-2015.

Table 1-3. Comparison of total nitrogen methods for samples collected January 2013 through September 2015 at water-quality-monitoring stations on the Blackstone, Branch, Pawtuxet, and Pawcatuck Rivers in Massachusetts and Rhode Island.

Table 1-4. Flux-bias statistics for samples collected from water years 1979 through 2015 (2007 through 2015 for streamgage 01113895, and 1979 through 2014 for nitrite plus nitrate for streamgage 01111230) for selected constituents at water-quality-monitoring stations on the Blackstone, Pawtuxet, and Pawcatuck Rivers in Massachusetts and Rhode Island. 


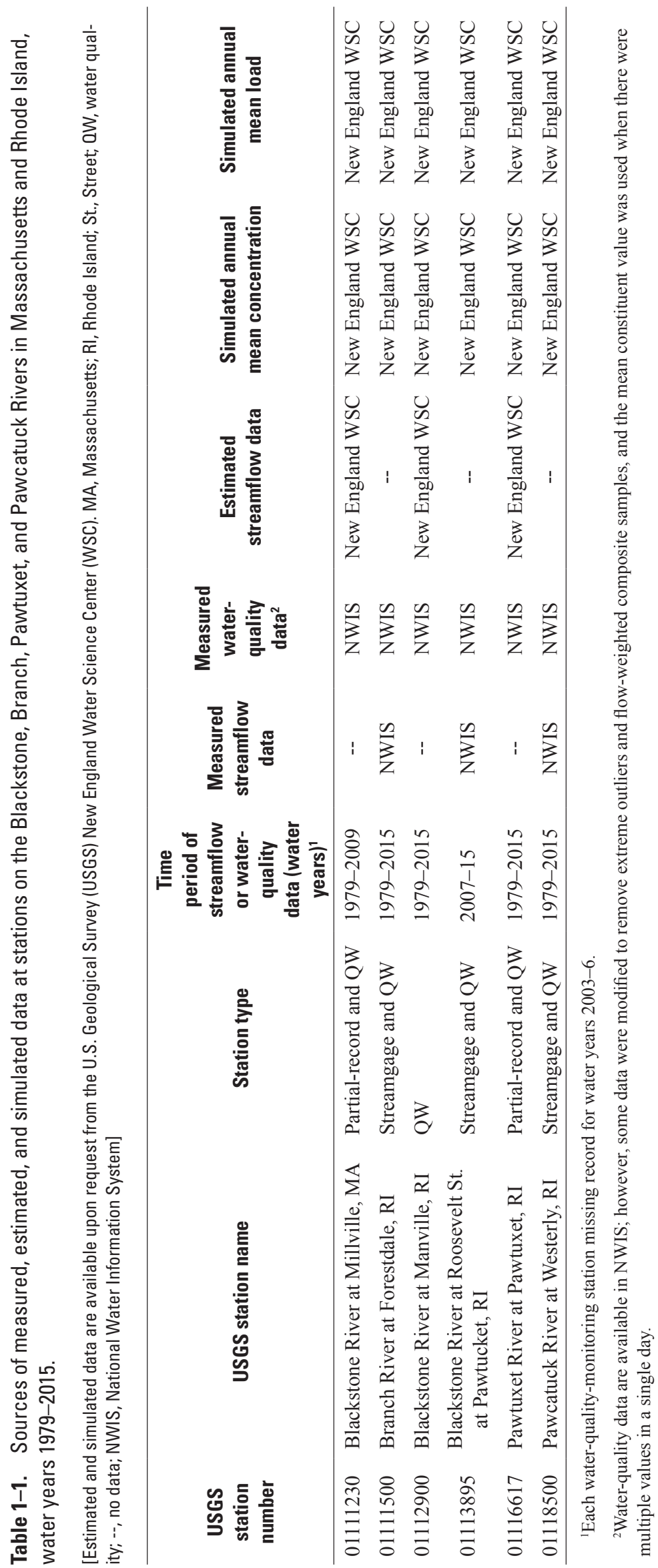


Table 1-2. Summary of water-quality laboratory method references for samples collected at water-quality-monitoring stations on the Blackstone, Branch, Pawtuxet, and Pawcatuck Rivers in Massachusetts and Rhode Island, 1979-2015.

[No samples were collected from September 2002 through February 2007. USGS, U.S. Geological Survey]

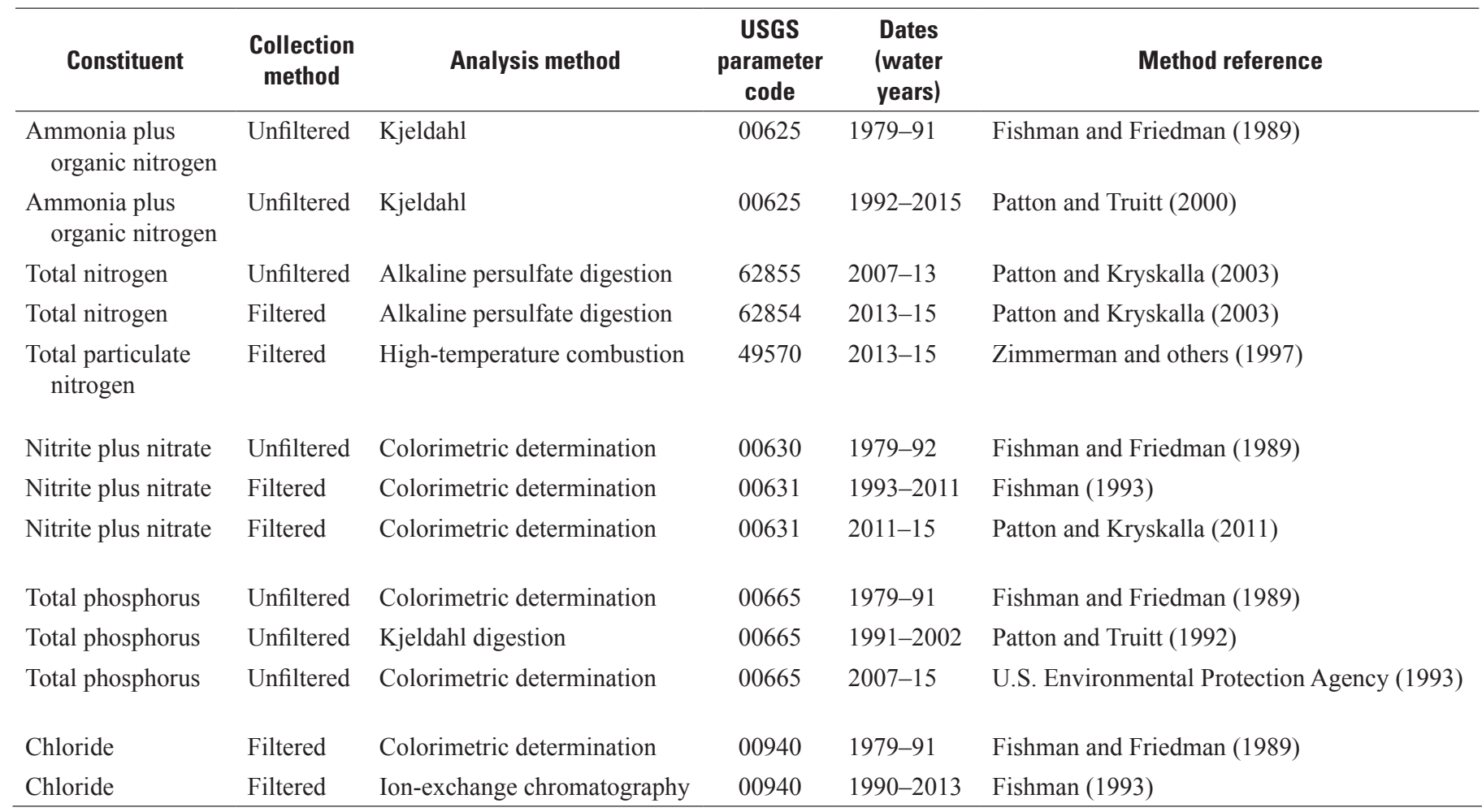

Table 1-3. Comparison of total nitrogen methods for samples collected January 2013 through September 2015 at water-qualitymonitoring stations on the Blackstone, Branch, Pawtuxet, and Pawcatuck Rivers in Massachusetts and Rhode Island.

[mg/L, milligram per liter]

\begin{tabular}{|c|c|c|c|}
\hline Comparison & $\begin{array}{c}\text { Num- } \\
\text { ber of } \\
\text { samples } \\
\text { 2013-2015 }\end{array}$ & $\begin{array}{c}\text { Mean } \\
\text { relative } \\
\text { percent } \\
\text { difference }\end{array}$ & $\begin{array}{c}\text { Mean } \\
\text { differ- } \\
\text { ence } \\
\text { (mg/L) }\end{array}$ \\
\hline $\begin{array}{l}\text { [Total nitrogen alkaline persulfate digestion }(62855)]-[\text { filtered nitrogen persulfate digestion }(62854)+ \\
\text { total particulate nitrogen }(49570)]\end{array}$ & 144 & -2.973 & -0.029 \\
\hline
\end{tabular}


Table 1-4. Flux-bias statistics for samples collected from water years 1979 through 2015 (2007 through 2015 for streamgage 01113895 , and 1979 through 2014 for nitrite plus nitrate for streamgage 01111230) for selected constituents at water-quality-monitoring stations on the Blackstone, Pawtuxet, and Pawcatuck Rivers in Massachusetts and Rhode Island.

[USGS, U.S. Geological Survey; MA, Massachusetts; RI, Rhode Island; St., Street]

\begin{tabular}{|c|c|c|c|c|c|}
\hline $\begin{array}{c}\text { USGS } \\
\text { station number }\end{array}$ & USGS station name & Total nitrogen & Nitrite plus nitrate & Total phosphorus & Chloride \\
\hline 01111230 & Blackstone River at Millville, MA & -0.0043 & -0.011 & -0.036 & 0.007 \\
\hline 01112900 & Blackstone River at Manville, RI & 0.0057 & 0.002 & -0.010 & -0.002 \\
\hline 01113895 & Blackstone River at Roosevelt St. at Pawtucket, RI & 0.0002 & -0.012 & 0.041 & 0.015 \\
\hline
\end{tabular}

\section{References Cited}

Fishman, M.J., ed., 1993, Methods of analysis by the U.S. Geological Survey National Water Quality LaboratoryDetermination of inorganic and organic constituents in water and fluvial sediments: U.S. Geological Survey OpenFile Report 93-125, 217 p., accessed August 25, 2016, at https://pubs.er.usgs.gov/publication/ofr93125.

Fishman, M.J., and Friedman, L.C., eds., 1989, Methods for determination of inorganic substances in water and fluvial sediments: U.S. Geological Survey Techniques of Water-Resources Investigations, book 5, chap. A1, 545 p., accessed March 11, 2016, at https://pubs.usgs.gov/twri/ twri5-a1/.

Patton, C.J., and Kryskalla, J.R., 2003, Methods of analysis by the U.S. Geological Survey National Water Quality Laboratory-Evaluation of alkaline persulfate digestion as an alternative to Kjeldahl digestion for determination of total and dissolved nitrogen and phosphorus in water: U.S. Geological Survey Water-Resources Investigations Report 03-4174, $33 \mathrm{p}$.

Patton, C.J., and Kryskalla, J.R., 2011, Colorimetric determination of nitrate plus nitrite in water by enzymatic reduction, automated discrete analyzer methods: U.S. Geological Survey Techniques and Methods, book 5, chap. B8, 34 p., accessed April 12, 2016, at http://pubs.usgs.gov/tm/05b08/.
Patton, C.J., and Truitt, E.P., 1992, Methods of analysis by the U.S. Geological Survey National Water Quality Laboratory; determination of the total phosphorus by a Kjeldahl digestion method and an automated colorimetric finish that includes dialysis: U.S. Geological Survey Open-File Report 92-146, 39 p., accessed April 12, 2016, at http://pubs.er.usgs.gov/publication/ofr92146.

Patton, C.J., and Truitt, E.P., 2000, Methods of analysis by the U.S. Geological Survey National Water Quality Laboratory-Determination of ammonium plus organic nitrogen by a Kjeldahl digestion method and an automated photometric finish that includes digest cleanup by gas diffusion: U.S. Geological Survey Open-File Report 00-170, 31 p., accessed April 12, 2016, at http://pubs.usgs.gov/ of/2000/0170/report.pdf.

U.S. Environmental Protection Agency, 1993, Determination of phosphorus by semi-automated colorimetry (revision 2.0), method 365.1 of Methods for the determination of inorganic substances in environmental samples: U.S. Environmental Protection Agency EPA/600/R-93/100, p. 365.1-1-365.1-17.

Zimmerman, C.F., Keefe, C.W., and Bashe, Jerry, 1997, Method 440.0 - Determination of carbon and nitrogen in sediments and particulates of estuarine/coastal waters using elemental analysis: U.S. Environmental Protection Agency EPA/600/R-15/009, 10 p. [Also available at https://cfpub.epa.gov/si/si_public_record_report. cfm?dirEntryId=309418.] 


\section{Appendix 2. Streamflow Estimation}




\section{Maintenance of Variance Extension, Type 1 (MOVE.1) Streamflow Estimation}

This study included two partial-record stations (Blackstone River at Millville, Massachusetts [streamgage 01111230], and Pawtuxet River at Pawtuxet, Rhode Island [streamgage 01116617]) with miscellaneous streamflow measurements and one water-quality-monitoring station (Blackstone River at Manville, R.I. [streamgage 01112900]) with no streamflow data (fig. 1, table 1). For these three stations, estimates of daily mean streamflow were needed for water years ${ }^{1} 1979-2015$ for computation of water-quality loads. For all three stations, a nearby streamgage (fig. 1; table 1) upstream or downstream from the station was used to estimate daily mean streamflow.

For partial-record stations, miscellaneous streamflow measurements are related to the concurrent daily mean streamflows at nearby streamgages. The selection of a streamgage for relation to a partial-record station is based on proximity; similarity of the physical, land-cover, land-use, surficial-deposit, and climatic characteristics between the two stations; and the linearity and Pearson's correlation coefficient $(r)$ of the relation between concurrent streamflows. All three stations were near streamgages on the same rivers that had similar basin, land-use, and climatic characteristics. Additionally, there were no major withdrawals or discharges between the three stations in the nearby streamgage upstream or downstream from the stations.

For the two partial-record stations with miscellaneous streamflow measurements, the relation for estimating daily mean streamflow was defined by use of a streamflow-record extension technique known as the Maintenance of Variance Extension, type 1 (MOVE.1; Hirsch, 1982). The MOVE.1 equation is as follows:

$$
Y_{i}=Y+\left(\frac{S_{y}}{S_{x}}\right) \times\left(X_{i}-X\right)
$$

where

$$
\begin{gathered}
Y_{i} \quad \begin{array}{l}
\text { is the estimated daily mean streamflow at the } \\
\text { partial-record station, }
\end{array} \\
X_{i} \quad \text { is the daily mean streamflow at the nearby } \\
\text { streamgage, } \\
Y \quad \text { is the mean of the streamflow measurement at } \\
\text { the partial-record station, } \\
X \quad \text { is the mean of the concurrent (same day as } \\
Y \text { occurred) daily mean streamflow at the } \\
\text { nearby streamgage, } \\
S_{y} \quad \text { is the standard deviation of the streamflow } \\
\text { measurements at the partial-record station, }
\end{gathered}
$$

\footnotetext{
${ }^{1}$ In this report years are given as water years. A water year is defined as the 12 -month period from October 1 through September 30 and is designated by the calendar year in which it ends.
}

\author{
and \\ $S_{x} \quad$ is the standard deviation of the concurrent \\ daily mean streamflows at the nearby \\ streamgage.
}

The streamflow data used in the MOVE.1 equation are base-10 log transformed, and the resulting streamflow $\left(Y_{i}\right)$ must then be retransformed back to arithmetic units.

To estimate the daily mean streamflow at the two partialrecord stations, the Streamflow Record Extension Facilitator (SREF) computer program by Granato (2009), which implements the MOVE. 1 technique, was used. The SREF computer program makes a scatterplot of log-transformed streamflow measurements at the partial-record station, in relation to concurrent log-transformed daily mean streamflow at the nearby streamgage, to determine the nature and quality of the relations between the streamflow measurements. Graphical plots of the relations of the data were evaluated to make sure they were linear, which is required for the MOVE. 1 analyses. The SREF computer program determines the MOVE.1 equation and then inputs the daily mean streamflow at the nearby streamgage into the equation to estimate the daily mean streamflow at the partial-record station.

The daily mean streamflows at the streamgages for 1979-2015 were downloaded from the U.S. Geological Survey National Water Information System (NWIS) Web interface (http://nwis.waterdata.usgs.gov/nwis) by using the computer program Get National Water Information System Streamflow (Q) files (GNWISQ; Granato, 2009). The miscellaneous streamflow measurements at the two partial-record stations, used in the SREF computer program, were downloaded directly from NWIS.

For the partial-record station Blackstone River at Millville, Mass. (01111230), two streamgages are nearby on the Blackstone River. The closest streamgage which has the most similar basin, land-use, and climatic characteristics, the Blackstone River at Rt. 122 bridge near Uxbridge, Mass. (01111212) streamgage, has operated continuously only from July 14, 2006, to the present (2015; fig. 1, table 1). Thus, this streamgage was used only to estimate the daily mean streamflow for 2007-15. For 1979-2006, the closest operating streamgage with similar characteristics is the Blackstone River at Woonsocket, R.I. (01112500) streamgage (fig. 1; table 1). For both periods, 1979-2006 and 2007-15, there is a good relation between the nearby streamgages and the partial-record station, as the Pearson's correlation coefficients were $r=0.985$ (for streamgage 01112500) and 0.998 (for streamgage 01111212). For the partial-record station Pawtuxet River at Pawtuxet, R.I. (01116617), the closest streamgage with similar basin, land-use, and climatic characteristics that operated for 1979-2015 is the Pawtuxet River at Cranston, R.I. (01116500) streamgage. The Pearson's correlation coefficient for this relation was $r=0.9600$ (table 2-1).

A scatterplot with the MOVE.1 equation for estimating daily mean streamflow at the partial-record station Blackstone River at Millville, Mass. (01111230), for 1979-2006, using the Blackstone River at Woonsocket, R.I., streamgage 
(01112500), is shown in figure 2-1. A scatterplot with the MOVE. 1 equation for 2007-15, using the Blackstone River at Rt. 122 bridge near Uxbridge, Mass., streamgage (01111212), is shown in figure 2-2. A scatterplot with the MOVE.1 equation for estimating daily mean streamflow at the partial-record station Pawtuxet River at Pawtuxet, R.I. (01116617), using the Pawtuxet River at Cranston, R.I., streamgage (01116500) for 1979-2015, is shown in figure 2-3. Information on each of the MOVE. 1 relations and variables for the equation are listed in table $2-1$.

The MOVE. 1 daily mean streamflow estimates for the partial-record stations Blackstone River at Millville, Mass. (01111230), and Pawtuxet River at Pawtuxet, R.I. (01116617), likely have more error at the higher streamflows than at the low to medium streamflows. This is because at the higher streamflows there are few concurrent streamflow measurements at the partial-record stations to pair with daily mean streamflow values at the nearby streamgages (figs. $2-1,2-2$, and 2-3). As shown in table 2-1, the maximum estimated daily mean streamflows at the partial-record stations were about 1.6 to 4.7 times higher than the measured streamflows used to develop the MOVE. 1 equations. The estimated low to medium streamflows at the partial-record stations have less error because there are many concurrent data values (figs. $2-1$, $2-2$, and 2-3) and the minimum measured streamflows used to develop the MOVE.1 equations are similar to the estimated minimum daily mean streamflow values (table $2-1$ ).

\section{Drainage-Area-Ratio Method of Streamflow Estimation}

For water-quality-monitoring station Blackstone River at Manville, R.I. (01112900), there were no streamflow data

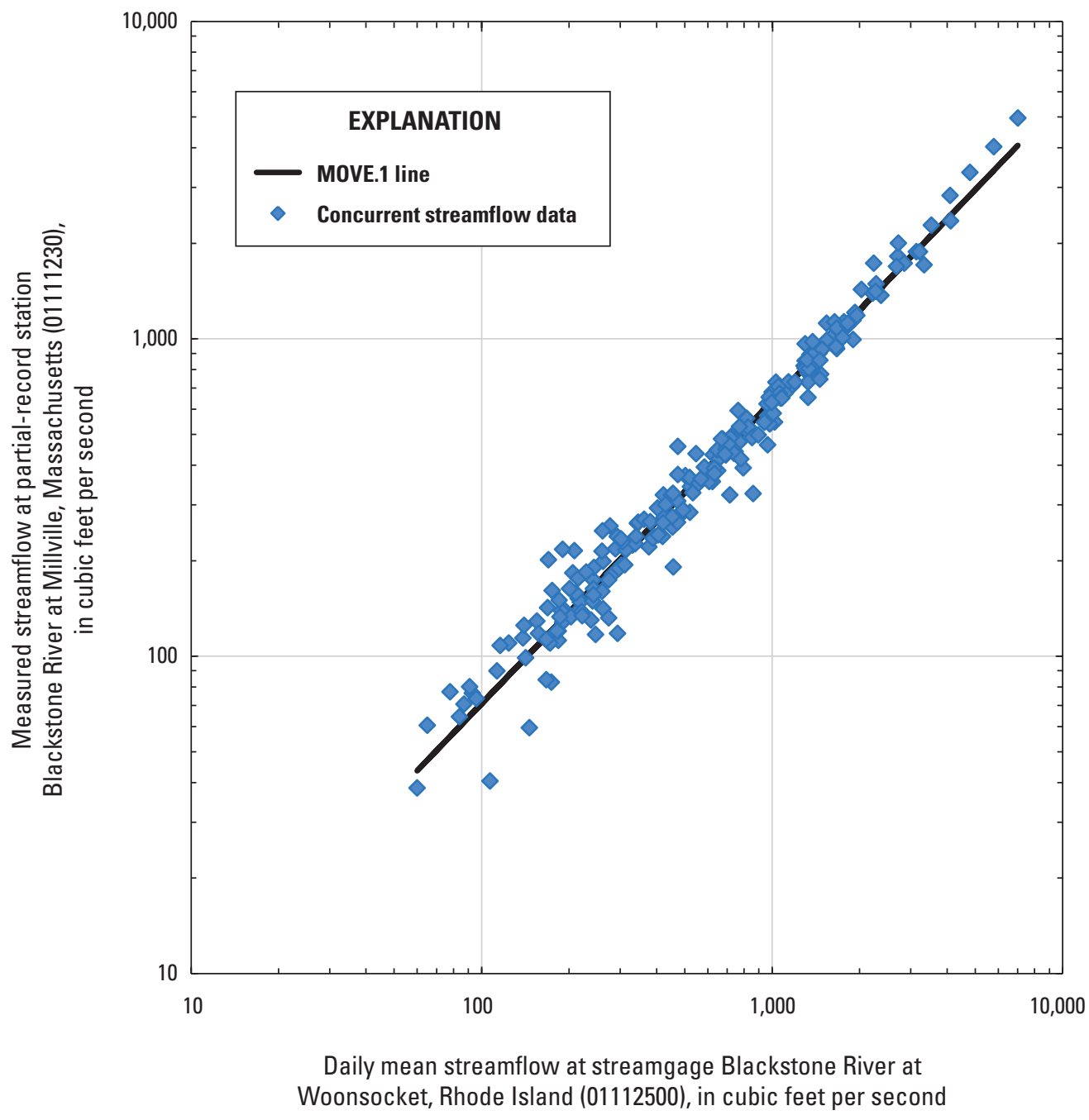

Figure 2-1. Plot showing Maintenance of Variance Extension, type 1 (MOVE.1) equation and concurrent streamflow data at Blackstone River at Woonsocket, Rhode Island (01112500), used for estimating daily mean streamflow at partial-record station Blackstone at Millville, Massachusetts (01111230), 1979 through 2006. 


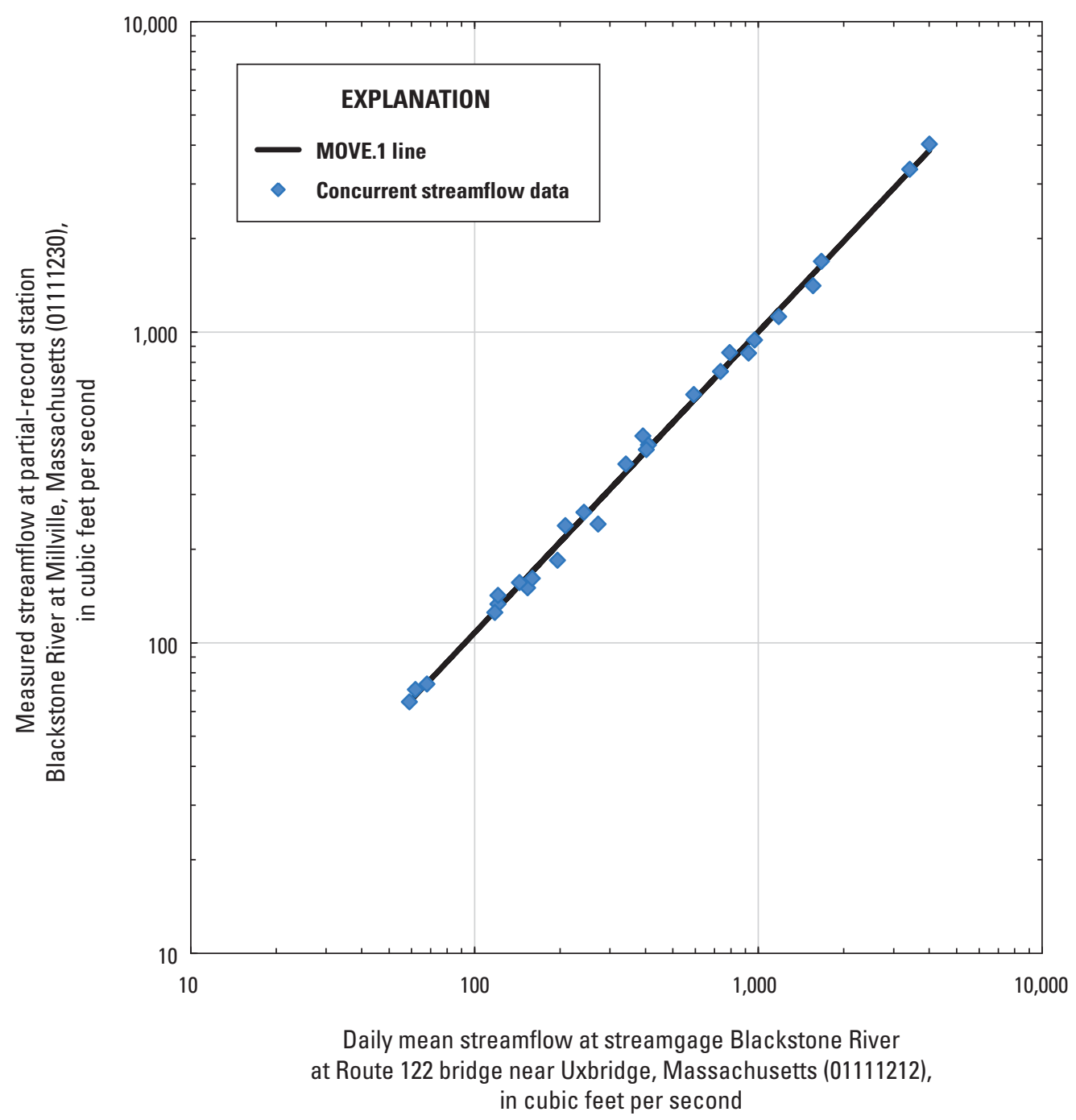

Figure 2-2. Plot showing Maintenance of Variance Extension, type 1 (MOVE.1) equation and concurrent streamflow data at Blackstone River at Route 122 bridge, near Uxbridge, Massachusetts (01111212), used for estimating daily mean streamflow at partial-record station Blackstone at Millville, Mass. (01111230), 2007 through 2015. 


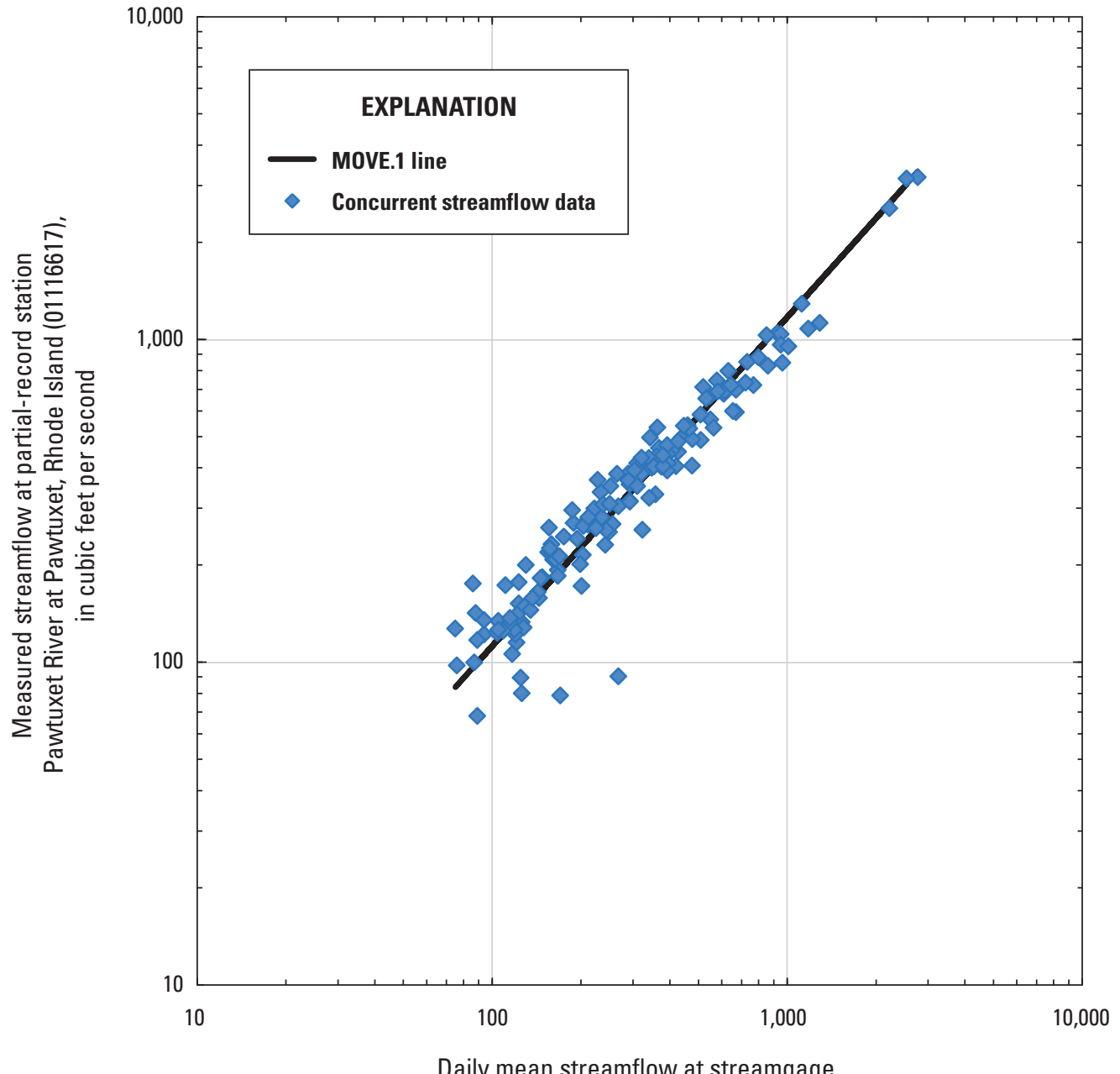

Pawtuxet River at Cranston, Rhode Island (01116500),

in cubic feet per second

Figure 2-3. Plot showing Maintenance of Variance Extension, type 1 (MOVE.1) equation and concurrent streamflow data at Pawtuxet River at Cranston, Rhode Island (01116500), used for estimating daily mean streamflow at partial-record station Pawtuxet River at Pawtuxet, R.I. (01116617), 1979 through 2015. 
and daily mean streamflow for 1979-2015 was estimated by using the drainage-area-ratio method. The drainage-area-ratio method is described by the following equation (Johnstone and Cross, 1949):

$$
Q_{u}=\left(\frac{D A_{u}}{D A_{g}}\right) \times Q_{g},
$$

where

$Q_{u} \quad$ is the drainage-area-ratio weighted estimate of daily mean streamflow at the ungaged station,

$D A_{u} \quad$ is the drainage area at the ungaged station,

$D A_{g} \quad$ is the drainage area at the gaged station, and

$Q_{g} \quad$ is the daily mean streamflow at the gaged station.

To estimate daily mean streamflow at the Blackstone River at Manville, R.I., for 1979-2006, the drainage-area ratio of $1.0361\left(1,116\right.$ square kilometers $\left[\mathrm{km}^{2}\right] / 1,077 \mathrm{~km}^{2}$; table 1) was multiplied by the daily mean streamflow for the
Blackstone River at Woonsocket, R.I., streamgage (01112500). The drainage difference between the two stations is 3.61 percent, which is well within the acceptable range for this method.

\section{References Cited}

Granato, G.E., 2009, Computer programs for obtaining and analyzing daily mean streamflow data from the U.S. Geological Survey National Water Information System Web site: U.S. Geological Survey Open-File Report 2008-1362, 123 p., CD-ROM. [Also available at http://pubs.usgs.gov/ of/2008/1362/.]

Hirsch, R.M., 1982, A comparison of four streamflow record extension techniques: Water Resources Research, v. 18, no. 4, p. 1081-1088.

Johnstone, Don, and Cross, W.P., 1949, Elements of applied hydrology: New York, Ronald Press Co., 276 p. 

For more information concerning this report, contact: Director, New England Water Science Center U.S. Geological Survey

10 Bearfoot Road

Northborough, MA 01532

dc_nweng@usgs.gov

or visit our Web site at:

http://newengland.water.usgs.gov

Publishing support by:

The Pembroke Publishing Service Center. 


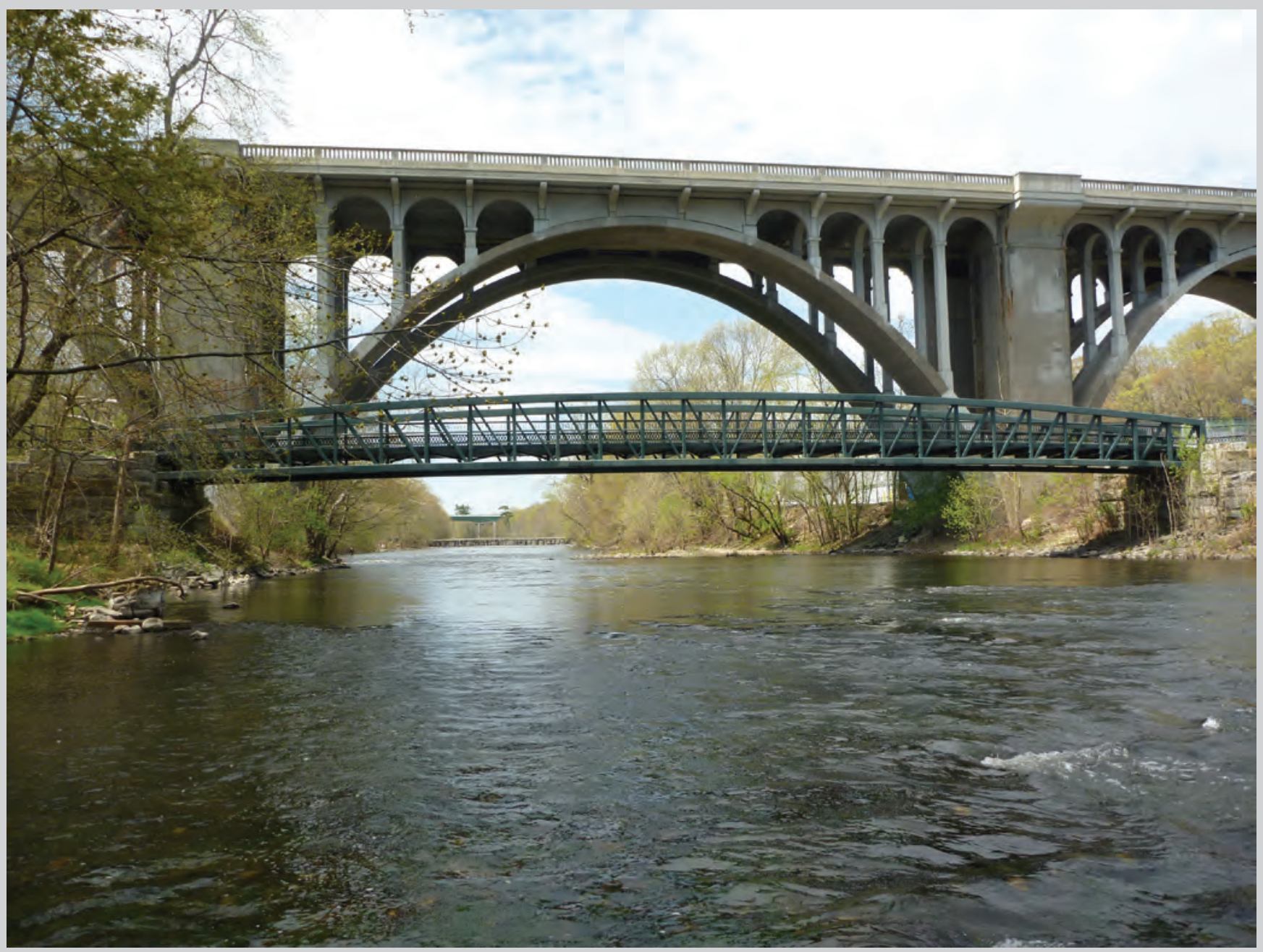

